\title{
1 Cadmium isotope fractionation during complexation with 2 humic acid
}

3 Gildas Ratié ${ }^{1}$, Vladislav Chrastný ${ }^{1}$, Damien Guinoiseau ${ }^{2,3}$, Rémi Marsac ${ }^{4}$,

4 Zuzana Vaňková ${ }^{1}$, Michael Komárek ${ }^{1 *}$

51 Department of Environmental Geosciences, Faculty of Environmental Sciences, Czech

6 University of Life Sciences Prague, Kamýcká 129, 165 00, Prague - Suchdol, Czech Republic

$7 \quad{ }^{2}$ Université de Paris, Institut de physique du globe de Paris, CNRS, F-75005 Paris, France

$8 \quad{ }^{3}$ Aix Marseille Univ, CNRS, IRD, INRAE, Coll France, CEREGE, Aix-en-Provence, France.

$9 \quad{ }^{4}$ Univ Rennes, CNRS, Géosciences Rennes - UMR 6118, F-35000 Rennes, France

10 *corresponding author: komarek@fzp.czu.cz

\section{Keywords}

12 cadmium isotopes; humic acid; carboxylic groups; non-specific binding; electrostatic attractions; cadmium 13 hydration complexes

\section{Abstract}

Cadmium (Cd) isotopes are known to fractionate during complexation with various

16 environmentally relevant surfaces and ligands. Our results, which were obtained using a combination of

17 various techniques and approaches, highlight the preferential enrichment of light $\mathrm{Cd}$ isotopes bound to

18 humic acid (HA), leaving preferentially the heavier Cd pool in the solution $\left(\Delta^{114 / 110} \mathrm{Cd}_{\mathrm{HA}-\mathrm{Cd}(\mathrm{aq})}\right.$ of $-0.15 \pm$

$190.01 \%$ ). At high ionic strengths, $\mathrm{Cd}$ isotope fractionation mainly depends on its complexation with

20 carboxylic sites. Outer-sphere complexation occurs at equilibrium together with inner-sphere

21 complexation as well as with the change of the first $\mathrm{Cd}$ coordination and its hydration complexes in

22 solution. At low ionic strengths, non-specific $\mathrm{Cd}$ binding induced by electrostatic attractions plays a

23 dominant role and promotes $\mathrm{Cd}$ isotope fractionation during complexation. This significant outcome 
24 elucidates the mechanisms involved in HA-Cd interactions. The results can be used during (i)

25 fingerprinting the available $\mathrm{Cd}$ in soil solution after its complexation with solid or soluble natural organic

26 matter and (ii) evaluate the contribution of $\mathrm{Cd}$ complexation with organic ligands and phytoplankton-

27 derived debris $v s$. Cd assimilation by phytoplankton in seawater.

\section{1. Introduction}

Besides other "non-traditional" isotopes that have been studied increasingly during the last couple

30 of decades, $\mathrm{Cd}$ has drawn much interest as the knowledge of $\mathrm{Cd}$ isotope systematics is crucial for a

31 thorough understanding of the Earth's $\mathrm{Cd}$ geochemistry cycle. Pilot studies involving Cd isotopes date

32 back to the 1970 s, when large variations were measured in meteoritic and extraterrestrial materials. ${ }^{1,2}$

33 Cadmium has six stable isotopes $\left({ }^{106} \mathrm{Cd},{ }^{108} \mathrm{Cd},{ }^{110} \mathrm{Cd},{ }^{111} \mathrm{Cd},{ }^{112} \mathrm{Cd},{ }^{114} \mathrm{Cd}\right)$ and its isotope systematics can

34 be used in different fields: (i) marine biogeochemistry and oceanography, given the nutrient-like behavior

35 of $\mathrm{Cd}$ and its close correlation with algal nutrients, e.g., nitrate and phosphate, ${ }^{3-6}$ (ii) Cd plant uptake in the

36 soil-plant system influenced by the applications of mineral P fertilizers containing $\mathrm{Cd}$ and the risk of $\mathrm{Cd}$

37 transfer into the food chain, ${ }^{7-11}$ and (iii) natural and anthropogenic source tracking based on the large

38 isotope fractionation induced by evaporation and condensation processes during industrial $\mathrm{Cd}$

39 emissions. $^{12-15}$

40 Despite these numerous environmental studies, there is a surprising lack of a fundamental 41 understanding of $\mathrm{Cd}$ isotope fractionation at specific conditions. Bioavailability, mobility, and toxicity of

$42 \mathrm{Cd}$ depend on its speciation in the natural system. Cadmium does not undergo natural redox reactions in 43 such natural settings, so the most likely processes affecting its mobility are precipitation and 44 adsorption/complexation with mineral or organic particles. Only four laboratory experiments have been 45 conducted to quantify $\mathrm{Cd}$ isotope fractionation during adsorption ${ }^{16}$ and (co)precipitation. ${ }^{17-19}$ The results 46 showed that lighter $\mathrm{Cd}$ isotopes are preferentially adsorbed to Mn-oxyhydroxides ${ }^{16}\left(\Delta^{114 / 110} \mathrm{Cd}_{\text {solid-Cd(aq) }}=\right.$ 470.54 to $-0.24 \%$ ) and precipitated to calcite ${ }^{17}\left(\Delta^{114 / 110} \mathrm{Cd}_{\mathrm{CaCO}-\mathrm{Cd}(\mathrm{aq})} \approx-0.45 \%\right.$ ) or as $\mathrm{CdS}^{18}$ (closed-system 48 Rayleigh fractionation model $1.00028<\alpha_{\mathrm{Cd}(\mathrm{aq})-\mathrm{CdS}}<1.00052$ for ${ }^{114} \mathrm{Cd} /{ }^{110} \mathrm{Cd}$ ). 
The mobility of $\mathrm{Cd}$ and its inherent toxicity to living organisms and humans ${ }^{20-22}$ has motivated the

50 scientific community to understand its sources and behavior in the environment. ${ }^{23}$ By the end of the $1980 \mathrm{~s}$,

51 Cd mobilization from anthropogenic sources (mining, metal smelting, manufacturing, and fertilizer use)

52 was more than 5,000 times higher than from natural weathering. ${ }^{24}$ Therefore, significant Cd amounts were

53 remobilized in the biosphere resulting in an enrichment in the atmosphere, soils, sediments, and aquatic

54 environments relative to its concentration in the continental crust. ${ }^{25,26}$ Organo-Cd complexes are usually

55 the primary chemical $\mathrm{Cd}$ species at different biogeochemical interfaces, i.e., soil-plants, sediment-surface

56 waters-ocean, and strongly influence its behavior and fate in the environment. ${ }^{10,27,28}$ The principal

57 components of natural organic matter (NOM) are humic substances, i.e., fulvic acids, humin, and humic

58 acids (HA), the latter being a heterogeneous high-molecular-weight organic material, which is ubiquitous

59 in terrestrial (soil, peat) and aquatic environments (sediment, ocean, and freshwater), in both soluble and

60 insoluble forms. ${ }^{29-31}$ The physical, chemical, and microbiological transformations of plant, animal, algal,

61 and microbial material ${ }^{32}$ lead to the formation of HA through different humification processes, ${ }^{30}$

62 generating variable and complex organic molecules. Humic acids are an important source of dissolved

63 complexing organic ligands, such as carboxylic and phenolic hydroxyl groups ${ }^{33}$ and these complexes

64 affect the speciation of metal ions, together with their bioavailability, mobility, and toxicity. ${ }^{34-37}$

65 Therefore, Cd complexation by $\mathrm{HA}$ is a crucial process influencing the biogeochemical cycling of $\mathrm{Cd}$ in

66 the ocean, in the soil-plant system, or in general, during its remobilization in the environment.

The first objective of this study is to examine $\mathrm{Cd}$ complexation with a commonly used representative HA, i.e., leonardite humic acid, at different experimental conditions (Cd concentration,

69 ionic strength, $\mathrm{pH}$ ). The second objective is to determine the $\mathrm{Cd}$ isotope fractionation occurring during $\mathrm{Cd}$

70 complexation with HA under the same experimental conditions by measuring both dissolved (aqueous Cd)

71 and complexed (Cd bound to HA) phases. Finally, combining Fourier transformation infrared (FTIR), X-

72 ray absorption spectroscopy (XAS), and modeling, our study highlights the complexation mechanisms

73 leading to $\mathrm{Cd}$ isotope fractionation during its complexation with HA. 


\section{2. Materials and Methods}

\section{2.1. Sorption experiments}

76

\subsubsection{Leonardite humic acid}

Leonardite (humic acid) was chosen due to its high potential for complexation of metal(loid)s in aqueous solutions ( $\mathrm{As}, \mathrm{Cd}, \mathrm{Cu}, \mathrm{Pb}, \mathrm{Ni}$, etc.) and because it is commonly used as a NOM proxy. ${ }^{38-40}$ Leonardite is a coal-like substance and is believed to be derived from lignitic coal via natural oxidation. ${ }^{41}$ Leonardite has a greater oxygen content than lignite due to a larger number of carboxylic groups. Leonardite is composed of phenolic and carboxylic $\mathrm{OH}$ groups, aliphatic $\mathrm{CH}$ groups, and carbonyl groups together with conjugated carbonyl or aromatic groups ${ }^{41}$. In this study, leonardite HA was obtained from the International Humic Substances Society (IHSS) $(\mathrm{C}=63.8 \%, \mathrm{O}=31.3 \%, \mathrm{H}=3.70 \%$ and $\mathrm{N}=1.23 \%$, HA/DOC $=1.57)$ and characterized by infrared spectroscopy (Fig. S1). For Fourier transform infrared spectroscopy (FTIR) analysis, samples were grounded with $\mathrm{KBr}$ at a 1/100 mass ratio and then pressed into disks. FTIR spectra were recorded using a FTIR spectrometer (Perkin Elmer) between 5000 and 400 $\mathrm{cm}^{-1}$ at a resolution of $0.5 \mathrm{~cm}^{-1}$.

Leonardite was solubilized at $\mathrm{pH}$ between 9 and 10 (adding $1 \mathrm{~mol} \mathrm{~L}^{-1} \mathrm{NaOH}$ ) to ensure complete dissolution. ${ }^{42}$ Then, any possibly present HA molecules $<10 \mathrm{kDa}$ were removed using the Labscale TFF system equipped with a Pellicon XL membrane ${ }^{43}$ (PLCGC10, Millipore). The dissolved organic carbon (DOC) concentrations were measured by the Carbon Analyzer (TOC-L CPH, Shimadzu). Further in this work, humic acid (HA) denotes leonardite for simplification purposes.

\subsubsection{Cd adsorption edges}

Adsorption edges were obtained using batch experiments in opaque plastic bottles to avoid any photoluminescence process. All plastic containers were acid-washed, and all reagents used were of reagent grade. Adsorption experiments with Cd ICP standard (Merck standard) were performed under $\mathrm{N}_{2}$ atmosphere at three different initial metal concentrations $\left(10^{-6}, 10^{-5}\right.$, and $\left.10^{-4} \mathrm{~mol} \mathrm{~L}^{-1}\right)$ and three ionic strengths $\left(10^{-1}, 10^{-2}\right.$, and $10^{-3}$ mol L-1 with $\mathrm{NaNO}_{3}$ as a background electrolyte). The DOC concentration 
99 was fixed for each batch experiment at $60 \mathrm{mg} \mathrm{L}^{-1}$. A volume of 60 to $75 \mathrm{~mL}$ was used for each batch 100 experiment, and the $\mathrm{pH}$ was buffered by adding a controlled volume of $\mathrm{HNO}_{3}\left(10^{-1}, 10^{-2}\right.$, and $\left.10^{-3} \mathrm{~mol} \mathrm{~L}^{-1}\right)$ 101 and $\mathrm{NaOH}\left(10^{-1}, 10^{-2}\right.$, and $\left.10^{-3} \mathrm{~mol} \mathrm{~L}^{-1}\right)$ ranging from 2 to $11 \mathrm{pH}$ units. Each bottle was then closed and 102 agitated for $24 \mathrm{~h}$. After equilibration, the $\mathrm{pH}$ was measured, and an aliquot of the sample (12 mL) was 103 centrifuged using a centrifugal filter device at $6600 \mathrm{rpm}$ for 45 minutes (Amicon ${ }^{\circledR}$ Ultra-15 centrifugal

104 filter devices $3 \mathrm{kDa}$ ). Before the ultrafiltration, the centrifugal filter device was washed with $\mathrm{NaOH} 0.05$ $105 \mathrm{~mol} \mathrm{~L}^{-1}$ and MilliQ ${ }^{\circledR}$ water to remove trace amounts of glycerin that could have interfered with the 106 measurements. The filtrate was analyzed for Cd concentration using inductively coupled plasma optical 107 emission spectroscopy (ICP OES; 720 Series, Agilent Technologies) or inductively coupled plasma mass 108 spectroscopy (ICP-MS; iCAP Q, Thermo Fisher Scientific), depending on Cd concentrations. Cadmium 109 bound to HA was calculated as the difference between the initial $\mathrm{Cd}$ concentration and the final $\mathrm{Cd}$ 110 concentration in the filtrates.

\section{$111 \quad$ 2.1.3. Complexation modeling}

112 The datasets of the adsorption edges were used further for the modeling using Visual MINTEQ 113 software. ${ }^{44}$ The NICA-Donnan model was used for our purpose, which results in a combination of non114 ideal competitive adsorption (NICA) to a heterogeneous material, coupled with a Donnan electrostatic 115 sub-model, describing the electrostatic attractions between ions and the humic material. ${ }^{45-47}$ The 116 distribution between the low adsorption sites (LAS, i.e., carboxylic sites) and high adsorption sites (HAS, 117 i.e., phenolic sites) was calculated using the HH-10, i.e., leonardite HA, binding parameters ${ }^{48}$ and the 118 generic NICA-Donnan model parameters for Cd-ion binding by humic acids. ${ }^{49}$ In our study, the 119 thermodynamic NICA-Donnan model parameters for Cd-ion binding to HA were slightly modified (Table 120 S1). 


\subsubsection{Batch experiments}

Adsorption experiments with a Cd isotope standard (NIST SRM $3108 \mathrm{Cd}$ ) were performed under

$124 \mathrm{~N}_{2}$ atmosphere at three fixed $\mathrm{pH}$ values $(4,5$, and 6$)$, three different initial metal concentrations $\left(2 \times 10^{-6}\right.$, $1252 \times 10^{-5}$, and $\left.2 \times 10^{-4} \mathrm{~mol} \mathrm{~L}^{-1}\right)$, five ionic strengths $\left(10^{-1}, 5 \times 10^{-2}, 10^{-2}, 5 \times 10^{-3}\right.$, and $10^{-3} \mathrm{~mol} \mathrm{~L}^{-1}$ with $\mathrm{NaNO}_{3}$ as

126 the background electrolyte). The DOC concentration $\left(120 \mathrm{mg} \mathrm{L}^{-1}\right)$ was increased two times from previous 127 batch experiments in order to obtain a sufficient amount of material for performing FTIR and XAS 128 measurements. The initial concentration of $\mathrm{Cd}$ was also doubled to maintain the same $\mathrm{Cd} / \mathrm{HA}$ ratio. In the 129 case of $10^{-6} \mathrm{~mol} \mathrm{~L}^{-1} \mathrm{Cd}$, only two fixed $\mathrm{pH}$ values were used (4 and 5) as $\mathrm{pH} 6$ did not allow us to analyze 130 the small amount of $\mathrm{Cd}$ in the solution. The batch experiment conditions were similar to those used for the 131 determination of the adsorption edges and HA was separated from the solution through a series of 132 ultrafiltrations (five times $12 \mathrm{~mL}$ on the same centrifugal filter device $3 \mathrm{kDa}$ ) at $6600 \mathrm{rpm}$ for 45 minutes. 133 Cadmium concentrations and isotope compositions were measured in the solution samples. The HA 134 fraction was recovered, freeze-dried, and used for EXAFS and FTIR measurements and for Cd isotope 135 analysis (nine HA samples) to determine the isotopic mass balance. Kinetic batch complexation 136 experiments were conducted to monitor the equilibration time of Cd isotope fractionation with HA at high $137\left(10^{-1} \mathrm{~mol} \mathrm{~L}^{-1} \mathrm{NaNO}_{3}\right)$ and low $\left(10^{-3} \mathrm{~mol} \mathrm{~L}^{-1} \mathrm{NaNO}_{3}\right)$ ionic strengths with a Cd concentration of $10^{-5} \mathrm{~mol} \mathrm{~L}^{-}$ $138{ }^{1}$ and DOC concentration of $120 \mathrm{mg} \mathrm{L}^{-1}$.

\subsubsection{Cadmium isotopes measurements}

140 Cadmium isotope ratios were measured using thermal ionization mass spectrometry (TIMS;

141 Triton, ThermoFisher), and Cd isotopic compositions are reported as $\delta^{114 / 110} \mathrm{Cd}$, relative to the NIST SRM 142 3108, with Eq. 1:

$$
\delta^{114 / 110} \mathrm{Cd}=\left(\frac{\left(\frac{{ }^{114} \mathrm{Cd}}{{ }^{110} \mathrm{Cd}}\right)_{\text {sample }}}{\left(\frac{{ }^{114} \mathrm{Cd}}{{ }^{110} \mathrm{Cd}}\right)_{\text {NIST SRM } 3108}}-1\right) \times 1,000
$$



purification procedure and the analysis, the double-spike (DS) method based on the nested iteration method was used. The DS was prepared by mixing two enriched $\mathrm{Cd}$ isotopes spikes: ${ }^{106} \mathrm{Cd}(97 \%)$ and ${ }^{116} \mathrm{Cd}(99 \%)$ purchased from IsoFlex, USA. The DS was added to the sample before the Cd separation process and was composed of ${ }^{106} \mathrm{Cd}(35 \%)$ and ${ }^{116} \mathrm{Cd}(65 \%)$. The natural/DS ratio was 5.6 for ${ }^{106} \mathrm{Cd} /{ }^{110} \mathrm{Cd}$ and 10.8 for ${ }^{116} \mathrm{Cd} /{ }^{10} \mathrm{Cd}$.

Before the Cd separation process, liquid samples were evaporated and transferred to bromide form, whereas HA samples were firstly dissolved in a mixture of concentrated $\mathrm{HNO}_{3}$ and $\mathrm{H}_{2} \mathrm{O}_{2}$ and then transferred to bromide form. Chromatographic separation of $\mathrm{Cd}$ was performed following the analytical methods previously published by Schmitt et al. ${ }^{50,51}$ and Abouchami et al. ${ }^{4,52}$ This technique was inspired by $\mathrm{Pb}$ separation and is promising because it is fast and requires only small amounts of acid. In comparison with Cd isotope measurements by MC-ICP MS, there were no isobaric interferences due to $\mathrm{Sn}$ and Pd isotopes, ${ }^{51}$ allowing us to skip the chemical separation of Sn using a second anion-exchange chromatography. This protocol was adapted in our laboratory using $400 \mu \mathrm{L}$ of the BioRad AG1-X8 anion exchange resin (100-200 mesh) in bromide form.

After $\mathrm{Cd}$ recovery, the sample was evaporated entirely on a hot plate $\left(110-120^{\circ} \mathrm{C}\right)$ to the last drop. After cooling, an activator was added to the sample depending on the amount of $\mathrm{Cd}$. For $500 \mathrm{ng}$ of $\mathrm{Cd}$, the activator was composed of $50 \mu \mathrm{L}$ of $\mathrm{H}_{3} \mathrm{PO}_{4} 0.1 \mathrm{~N}$ and $100 \mu \mathrm{L}$ of silica gel (100 mg L ${ }^{-1}$ of $\mathrm{Si}$ ). Then, the sample was evaporated to dryness and $10 \mu \mathrm{L}$ of $2 \% \mathrm{HNO}_{3}$ was added and treated by ultrasonication. The volume was loaded stepwise onto outgassed single Re filaments. Peak emission of $\mathrm{Cd}$ ions occurs in the temperature range from 1150 to $1200{ }^{\circ} \mathrm{C}$ with this activator. The signal varied between 0.2 to $0.5 \mathrm{~V}\left({ }^{112} \mathrm{Cd}\right.$, central cup) for the sample, and three complete measurements were feasible: 10 blocks of 20 cycles giving 600 measured values for the ${ }^{114} \mathrm{Cd} /{ }^{110} \mathrm{Cd}$ ratio. purification procedure was applied for standard solutions (BAM-I012 and NIST SRM 3108) and 
international soil standard (NIST SRM 2711a Montana soil II). During the experiment and purification,

170 the procedure blank was $4 \mathrm{pg}$ of $\mathrm{Cd}$, having a negligible impact on $\mathrm{Cd}$ isotopic composition. International 171 reference standard solutions BAM I012 and NIST SRM 3108 were analyzed, and the long-term external 172 precision was found to be $\pm 0.08 \%$ ( $2 \mathrm{SD}, \mathrm{n}=12$ ) and $\pm 0.02 \%$ ( $2 \mathrm{SD}, \mathrm{n}=3$ ), respectively. The measured $173 \delta^{114 / 110} \mathrm{Cd}$ value, relative to the NIST SRM 3108, was $-1.32 \pm 0.08 \%$ for BAM I012 ( $\mathrm{n}=12$, mean 174 published value ${ }^{53}:-1.33 \pm 0.43 \%$ ) and $0.57 \pm 0.02 \%$ for NIST $2711 \mathrm{a}$ Montana soil II ( $\mathrm{n}=10$, mean 175 published value ${ }^{54-56}: 0.55 \pm 0.03 \%$ ).

\subsection{Cd EXAFS measurements}

The Cd XAS spectra were collected on the SAMBA beamline (SOLEIL Synchrotron, France) at the Cd K-edge $(26.7 \mathrm{keV})$. The energy was calibrated by setting the first inflection point of a Cd metallic foil XANES. The reference $(\mathrm{CdO})$ and samples were prepared as pellets of finely ground and homogenized powder with boron nitride (15 mg of sample $+45 \mathrm{mg}$ of $\mathrm{BN}$ ) and then sealed with Kapton tape and mounted in sample holders. The data were collected under vacuum at $20 \mathrm{~K}$ using a He cryostat to avoid modification in $\mathrm{Cd}$ speciation and sample damage due to beam exposure. Spectra were collected in transmission (using an ionization chamber) and fluorescence modes. According to the spectrum quality, several spectra (up to 30 ) were collected over the $26.65-27.70 \mathrm{keV}$ energy range. Each raw bulk-XAS spectrum of Cd K-edge was merged and normalized, and the background was subtracted with a spline fitting function to obtain the extended X-ray absorption fine structure (EXAFS) function using Athena software. ${ }^{57}$ Fourier transforms were generated on $k^{3}$-weighted spectra over $k$-ranges of $1.5-15 \AA$ and 2-10 $\AA$ using the Hanning window for the reference $(\mathrm{CdO})$ and samples, respectively. Theoretical backscattering-amplitude $\left(\mathrm{S}_{0}{ }^{2}\right)$ and phase-shift $\left(\Delta \mathrm{E}_{0}\right)$ values were calculated using FEFF 6.0 (IFEFFIT package) based on the crystal structure of $\mathrm{CdO}$. The $\mathrm{S}_{0}{ }^{2}$ factor was set to 1.14159 . The known structure of $\mathrm{Cd}$ acetate dihydrate ${ }^{58}$ was used to find the structural parameters that best fit the observed spectrum for the HA samples. The goodness of fit was characterized by two parameters: the XAFS reliability factor R, 
193 which measures how close the fit is to the experimental data, and the reduced $\chi^{2}$ factor, which considers

194 the number of floating parameters and noise in the data.

\section{3. Results and discussion}

\subsection{Cadmium complexation with HA}

Cadmium complexation with HA depends on the $\mathrm{pH}$ and ionic strength and is complete in the $\mathrm{pH}$ range of 3 to 7 (Fig. 1 and S2). At low ionic strength, low competition between $\mathrm{Na}^{+}$and $\mathrm{Cd}^{2+}$ leads to a complete $\mathrm{Cd}$ complexation in acidic and neutral conditions. On the other hand, at high ionic strength, strong competition between $\mathrm{Na}^{+}$and $\mathrm{Cd}^{2+}$ led to a complete $\mathrm{Cd}$ complexation only in neutral and alkaline conditions. Additionally, the influence of the $\mathrm{Cd} / \mathrm{DOC}$ ratio highlights the diversity of HA binding groups, which are present in various proportions and cover a large range of affinity constants for $\mathrm{Cd}$. The presence of few high-affinity sites and many weaker sites resulted in complete $\mathrm{Cd}$ complexation at lower $\mathrm{pH}$ levels for low $\mathrm{Cd} / \mathrm{DOC}$ than for high $\mathrm{Cd} / \mathrm{DOC}$ ratios (Fig. 1). Complexation of $\mathrm{Cd}-\mathrm{HA}$ was investigated using 150 batch experiments under different experimental conditions (Cd concentration, ionic strength, and $\mathrm{pH}$ ).

This large experimental data set allowed us to precisely investigate and model Cd complexation with HA using the NICA-Donnan model. ${ }^{45,47,59,60}$

\subsection{Cadmium speciation during complexation with HA}

The NICA-Donnan model described four main Cd species (Fig. 2, S3, and S4): $\mathrm{Cd}^{2+}$ in solution $\left(\mathrm{Cd}^{2+}{ }_{\mathrm{aq}}\right)$, non-specifically bound $\mathrm{Cd}^{2+}$ (i.e., accumulated in the Donnan volume via electrostatic attractions, $\left.\mathrm{Cd}^{2+}{ }_{\mathrm{D}}\right), \mathrm{Cd}$ complexed with carboxylic groups (COO-Cd), and $\mathrm{Cd}$ complexed with phenolic groups (PhOCd). Furthermore, inorganic complexes, other than $\mathrm{Cd}^{2+}$ in solution, were only minor components of $\mathrm{Cd}$ aqueous speciation with contributions lower than $0.01 \%\left(\mathrm{Cd}(\mathrm{OH})^{+}, \mathrm{CdNO}_{3}{ }^{+}\right.$, etc. $)$. 


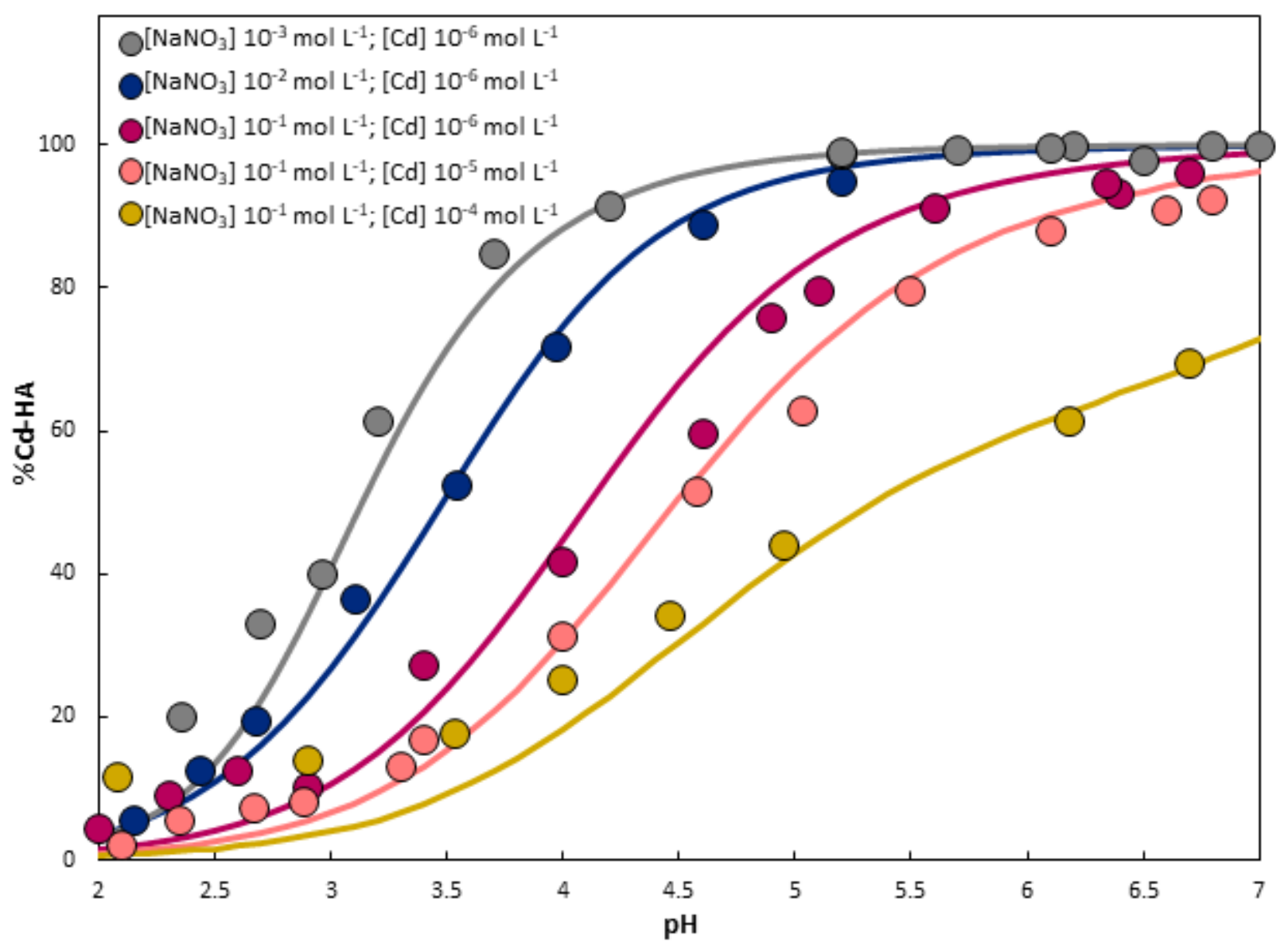

215 Figure 1: Cadmium complexation with $\mathrm{HA}\left(60 \mathrm{mg} \mathrm{L}^{-1} \mathrm{DOC}\right)$ at different $\mathrm{Cd}$ concentrations and ionic 216 strengths $\left(\mathrm{NaNO}_{3}\right.$ as background electrolyte) and as a function of $\mathrm{pH}$. Scatter plots express experimental 217 data, solid lines represent modeling by Visual MINTEQ (NICA-Donnan model). The ionic strength effect 218 on $\mathrm{Cd}$ complexation is highlighted at $10^{-6} \mathrm{~mol} \mathrm{~L}^{-1} \mathrm{Cd}$. The effect of the $\mathrm{Cd}$ concentration on the $\mathrm{Cd}$ 219 complexation is expressed at $10^{-1} \mathrm{~mol} \mathrm{~L}^{-1} \mathrm{NaNO}_{3}$. The remaining complexation dataset is shown in Figure 220 S2.

First, the formation of $\mathrm{Cd}(\mathrm{II})$-carboxyl complexes ${ }^{61}$ occurred in acidic and neutral conditions 222 because of the larger deprotonation of carboxylic groups compared with phenolic groups at low $\mathrm{pH}$ values 223 (Fig. 2a, S3a, and S4a). At low Cd concentrations $\left(10^{-6}\right.$ and $\left.10^{-5} \mathrm{~mol} \mathrm{~L}^{-1}\right)$, carboxylic groups complexed at 224 least $80 \%$ of total $\mathrm{Cd}$, while at a higher $\mathrm{Cd}$ concentration $\left(10^{-4} \mathrm{~mol} \mathrm{~L}^{-1}\right), \mathrm{Cd}$ complexation was limited to $22560 \%$ due to (i) site saturation, (ii) charge neutralization of HA which led to less favorable electrostatic 226 attractions, and (iii) conformational changes of $\mathrm{HA}$ that limited the site availability for Cd 227 complexation $^{62,63}$ (Fig. 2a, S3a, S4a). Although phenolic groups are high-affinity sites for cations, ${ }^{49} \mathrm{PhO}-$ 
228 Cd complexation was limited by the protonation of phenolic groups at pH levels between 2 and 7.

229 Therefore, most of Cd complexation in the environment will occur at this $\mathrm{pH}$ range from 3 to 7 and will be 230 mainly controlled by the carboxylic sites.

231 Secondly, ionic strength had a small effect on Cd complexation to carboxylic groups (Fig. 2b, 232 S3b, S4b), but it strongly affected non-specific binding of Cd with HA. Indeed, due to its amphiphilic 233 character, HA forms micelle-like structures ${ }^{64}$ acting as electrically neutral phases with a consistent 234 negative electrostatic potential (Donnan potential) compared to the solution. ${ }^{65}$ On the other hand, the 235 electrostatic potential is "neutralized" by the counterions from the background electrolyte $\mathrm{Na}^{+}{ }_{\text {aq }}$ and $\mathrm{Cd}^{2+}$ aq 236 in solution. ${ }^{45,66}$ As a result, the highest effect of electrostatic attractions between Cd and HA was observed 237 at $\mathrm{pH}$ around 4 and at low ionic strength. In these conditions, the carboxylic sites are weakly deprotonated 238 and the competition between $\mathrm{Cd}^{2+}$ and $\mathrm{Na}^{+}$in the Donnan volume is low (Fig. 2). That led to a prevalence 239 of non-specific Cd binding (up to $50 \%$ of total $\mathrm{Cd}, 60 \%$ of the total complexed $\mathrm{Cd}$ ) due to electrostatic 240 attractions. Furthermore, non-specific binding is almost absent in alkaline conditions, where phenolic and 241 carboxylic groups are deprotonated and ionic strength too high. However, at high Cd concentrations, there 242 are not enough deprotonated sites to bind all the $\mathrm{Cd}$ in solution and non-specific binding is still important 243 at pH 6-7 corresponding to $35 \%$ of total $\mathrm{Cd}$ due to the saturation of the binding sites (Fig. S3).

244 Finally, thermodynamic modeling allowed us to specify Cd speciation. Over the pH range from 3 245 to 7, Cd speciation is explained by the relative proportions of complexation with carboxylic groups (COO$246 \mathrm{Cd})$, non-specific Cd binding in the Donnan volume $\left(\mathrm{Cd}^{2+}{ }_{\mathrm{D}}\right)$, and the free $\mathrm{Cd}$ species in solution $\left(\mathrm{Cd}^{2+}{ }_{\mathrm{aq}}\right)$. 247 Consequently, the isotopic approach was designed to determine the $\mathrm{Cd}$ isotopic signature $\left(\delta^{114 / 110} \mathrm{Cd}\right)$ in 248 the same experimental conditions (Table 1) and to characterize the $\mathrm{Cd}$ isotope fractionation associated 249 with $\mathrm{Cd}$ binding to carboxylic groups or by electrostatic attractions. 

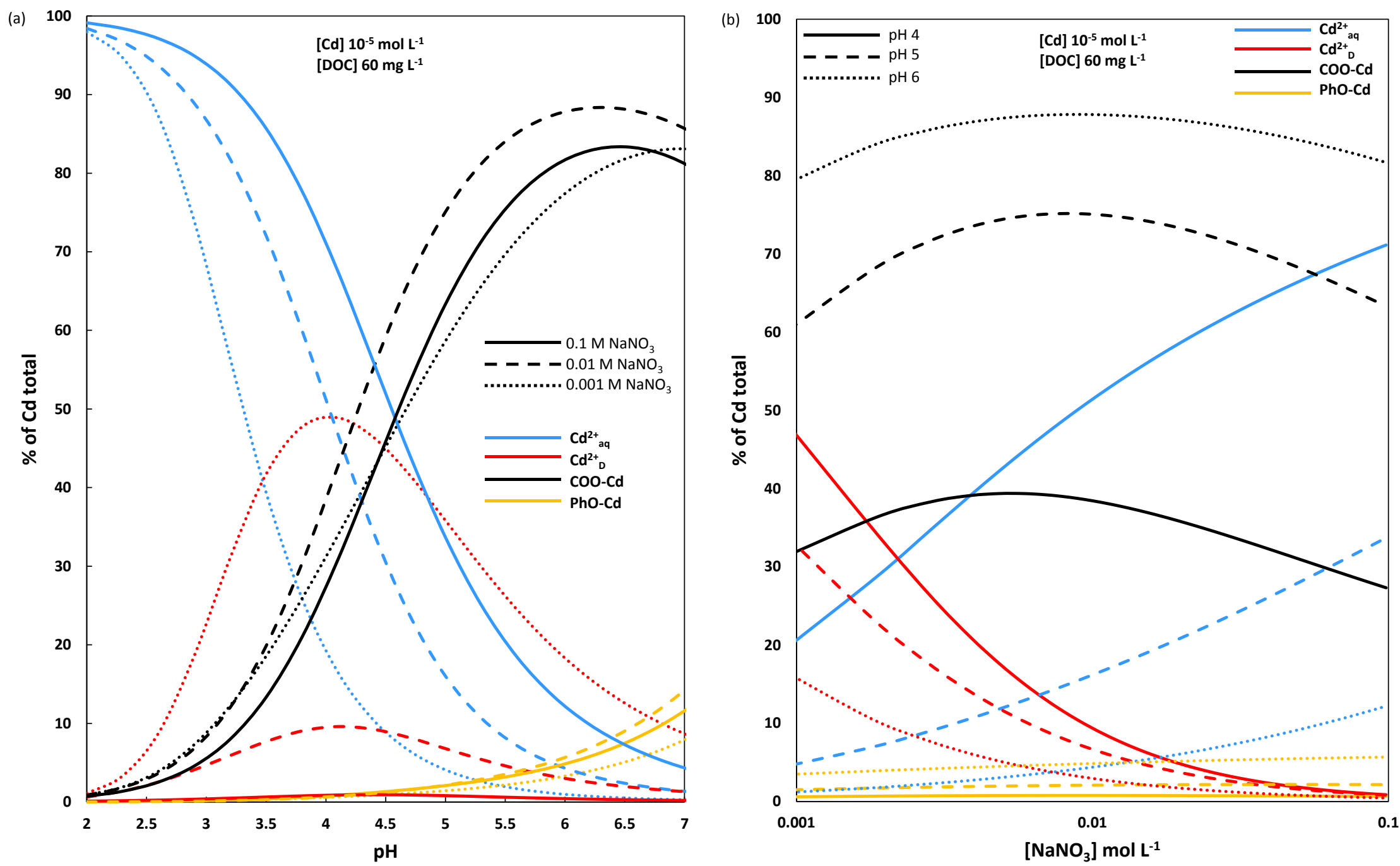

251 Figure 2: Cadmium speciation as a function of (a) $\mathrm{pH}$ and (b) ionic strength $\left(\mathrm{NaNO}_{3}\right)$. The data were determined using the NICA-Donnan model 252 for $10^{-5} \mathrm{~mol} \mathrm{~L}^{-1} \mathrm{Cd}$ and $60 \mathrm{mg} \mathrm{L}^{-1} \mathrm{DOC} . \mathrm{Cd}^{2+}{ }_{\text {aq }}$ refers to the aqueous Cd free in solution, $\mathrm{Cd}^{2+}{ }_{\mathrm{D}}$ to the Cd bound to HA by electrostatic attractions, 253 COO-Cd to the Cd complexed with carboxylic sites, and $\mathrm{PhO}-\mathrm{Cd}$ to the $\mathrm{Cd}$ complexed with phenolic sites. 
Table 1: Detailed experimental conditions and $\mathrm{Cd}$ isotope measurements in solution and in the HA fraction. The isotopic mass balance was calculated for 9 samples and did not exceed $0.03 \%$. The amount of Cd bound to HA by electrostatic attractions $\left(f\left(\mathrm{Cd}^{2+} \mathrm{D}\right)\right)$ and with the carboxylic groups $(f(\mathrm{COO}-\mathrm{Cd}))$ and aqueous $\mathrm{Cd}$ in solution $f\left(\mathrm{Cd}^{2+} \mathrm{aq}\right)$ were calculated based on the NICA-Donnan chemical speciation modeling (n.d.: not

257 determined).

\begin{tabular}{|c|c|c|c|c|c|c|c|c|c|c|c|c|c|}
\hline & pH solution & $\begin{array}{c}{\left[\mathrm{NaNO}_{3}\right] \mathrm{mol}} \\
\mathrm{L}^{-1} \text { solution } \\
\end{array}$ & $\begin{array}{l}f(\mathrm{Cd}) \text { in } \\
\text { solution }\end{array}$ & $\begin{array}{c}f\left(\mathbf{C d}^{2+}{ }_{\text {aq }}\right) \\
\text { model. }\end{array}$ & $\begin{array}{c}f\left(\mathrm{Cd}^{2+}{ }_{\mathrm{D}}\right) \\
\text { model }\end{array}$ & $\begin{array}{c}f(\mathrm{COO}-\mathrm{Cd}) \\
\text { model }\end{array}$ & $\begin{array}{c}\delta^{114 / 110} \mathrm{Cd} \\
\text { solution (\%) }\end{array}$ & & $2 \mathrm{SD}$ & $\begin{array}{l}\delta^{114 / 110} \mathrm{Cd} \\
\text { solid (\%o) } \\
\end{array}$ & & $2 \mathrm{SD}$ & $\begin{array}{l}\text { Isotopic } \\
\text { balance }\end{array}$ \\
\hline \multirow{15}{*}{$\begin{array}{c}{[\mathrm{Cd}] 2 \times 10^{-4}} \\
\mathrm{~mol} \mathrm{~L}^{-1} ; \\
{[\mathrm{DOC}] \mathbf{1 2 0}^{-120}} \\
\mathrm{mg} \mathrm{L}^{-1}\end{array}$} & 4.2 & $1.0 \mathrm{E}-01$ & 0.74 & 0.73 & 0.02 & 0.25 & 0.02 & \pm & 0.02 & -0.06 & \pm & 0.01 & 0.00 \\
\hline & 4.0 & $4.8 \mathrm{E}-02$ & 0.72 & 0.74 & 0.03 & 0.23 & 0.02 & \pm & 0.02 & & & & \\
\hline & 4.0 & $9.8 \mathrm{E}-03$ & 0.56 & 0.61 & 0.12 & 0.26 & 0.05 & \pm & 0.04 & & & & \\
\hline & 3.9 & $5.1 \mathrm{E}-03$ & 0.53 & 0.57 & 0.19 & 0.24 & 0.06 & \pm & 0.04 & & & & \\
\hline & 4.0 & $1.1 \mathrm{E}-03$ & 0.46 & 0.39 & 0.39 & 0.22 & 0.08 & \pm & 0.03 & -0.04 & \pm & 0.04 & 0.02 \\
\hline & 5.0 & $1.0 \mathrm{E}-01$ & 0.55 & 0.53 & 0.02 & 0.44 & 0.03 & \pm & 0.04 & & & & \\
\hline & 5.0 & 4.7E-02 & 0.40 & 0.48 & 0.03 & 0.48 & 0.05 & \pm & 0.01 & & & & \\
\hline & 4.9 & $1.0 \mathrm{E}-02$ & 0.30 & 0.37 & 0.12 & 0.50 & 0.08 & \pm & 0.00 & & & & \\
\hline & 4.9 & $5.3 \mathrm{E}-03$ & 0.25 & 0.31 & 0.19 & 0.49 & 0.10 & \pm & 0.02 & & & & \\
\hline & 4.9 & $1.1 \mathrm{E}-03$ & 0.20 & 0.17 & 0.42 & 0.41 & 0.12 & \pm & 0.02 & & & & \\
\hline & 6.2 & $1.0 \mathrm{E}-01$ & 0.33 & 0.36 & 0.01 & 0.57 & 0.08 & \pm & 0.01 & $\begin{array}{l}-0.01 \\
\end{array}$ & \pm & 0.03 & 0.02 \\
\hline & 5.9 & $4.8 \mathrm{E}-02$ & 0.25 & 0.34 & 0.03 & 0.59 & 0.09 & \pm & 0.01 & & & & \\
\hline & 6.0 & $9.5 \mathrm{E}-03$ & 0.12 & 0.21 & 0.11 & 0.64 & 0.09 & \pm & 0.05 & & & & \\
\hline & 5.4 & $4.5 \mathrm{E}-03$ & 0.14 & 0.21 & 0.20 & 0.57 & 0.13 & \pm & 0.01 & & & & \\
\hline & 5.8 & $1.1 \mathrm{E}-03$ & 0.07 & 0.07 & 0.38 & 0.53 & 0.16 & \pm & 0.02 & & & & \\
\hline \multirow{15}{*}{$\begin{array}{c}{[\mathrm{Cd}] 2 \times 10^{-5}} \\
\mathrm{~mol} \mathrm{~L}^{-1} ; \\
{[\mathrm{DOC}] 120} \\
\mathrm{mg} \mathrm{L}^{-1}\end{array}$} & 4.0 & $1.0 \mathrm{E}-01$ & 0.75 & 0.59 & 0.01 & 0.39 & 0.05 & \pm & 0.04 & $\begin{array}{l}-0.10 \\
\end{array}$ & \pm & 0.03 & 0.01 \\
\hline & 4.0 & 4.6E-02 & 0.61 & 0.51 & 0.03 & 0.45 & 0.04 & \pm & 0.01 & & & & \\
\hline & 4.0 & $1.1 \mathrm{E}-02$ & 0.37 & 0.37 & 0.13 & 0.49 & 0.09 & \pm & 0.04 & -0.01 & \pm & 0.08 & 0.03 \\
\hline & 4.1 & $5.7 \mathrm{E}-03$ & 0.26 & 0.27 & 0.21 & 0.52 & 0.12 & \pm & 0.04 & & & & \\
\hline & 4.0 & $1.2 \mathrm{E}-03$ & 0.16 & 0.12 & 0.52 & 0.35 & 0.17 & \pm & 0.03 & & & & \\
\hline & 5.1 & $1.0 \mathrm{E}-01$ & 0.37 & 0.20 & 0.01 & 0.76 & 0.07 & \pm & 0.02 & & & & \\
\hline & 5.1 & $5.1 \mathrm{E}-02$ & 0.21 & 0.15 & 0.02 & 0.80 & 0.11 & \pm & 0.03 & & & & \\
\hline & 5.1 & $1.1 \mathrm{E}-02$ & 0.09 & 0.09 & 0.07 & 0.82 & 0.13 & \pm & 0.04 & & & & \\
\hline & 5.0 & $4.9 \mathrm{E}-03$ & 0.05 & 0.06 & 0.14 & 0.78 & 0.15 & \pm & 0.02 & & & & \\
\hline & 5.0 & $1.1 \mathrm{E}-03$ & 0.02 & 0.02 & 0.36 & 0.61 & 0.19 & \pm & 0.04 & 0.01 & \pm & 0.09 & 0.01 \\
\hline & 6.0 & $9.9 \mathrm{E}-02$ & 0.15 & 0.07 & 0.00 & 0.87 & 0.11 & \pm & 0.02 & & & & \\
\hline & 6.0 & $5.2 \mathrm{E}-02$ & 0.09 & 0.05 & 0.01 & 0.88 & n.d. & & & & & & \\
\hline & 6.0 & $1.0 \mathrm{E}-02$ & 0.02 & 0.02 & 0.03 & 0.90 & 0.13 & \pm & 0.02 & & & & \\
\hline & 6.1 & $4.9 \mathrm{E}-03$ & 0.02 & 0.01 & 0.05 & 0.89 & 0.14 & \pm & 0.01 & & & & \\
\hline & 6.0 & $1.2 \mathrm{E}-03$ & 0.01 & 0.00 & 0.18 & 0.78 & 0.18 & \pm & 0.05 & 0.01 & \pm & 0.05 & 0.01 \\
\hline \multirow{10}{*}{$\begin{array}{c}{[\mathrm{Cd}] 2 \times 10^{-6}} \\
\mathrm{~mol} \mathrm{~L}^{-1} ; \\
{[\mathrm{DOC}] 120} \\
\mathrm{mg} \mathrm{L}^{-1}\end{array}$} & 4.1 & $1.0 \mathrm{E}-01$ & 0.54 & 0.36 & 0.01 & 0.61 & 0.08 & \pm & 0.02 & $\begin{array}{l}-0.07 \\
\end{array}$ & \pm & 0.01 & 0.01 \\
\hline & 4.1 & 4.6E-02 & 0.34 & 0.30 & 0.02 & 0.66 & 0.10 & \pm & 0.03 & & & & \\
\hline & 4.1 & $9.8 \mathrm{E}-03$ & 0.18 & 0.18 & 0.08 & 0.71 & 0.14 & \pm & 0.02 & & & & \\
\hline & 4.2 & $4.7 \mathrm{E}-03$ & 0.10 & 0.11 & 0.14 & 0.72 & n.d. & & & & & & \\
\hline & 4.2 & $9.8 \mathrm{E}-04$ & 0.06 & 0.04 & 0.41 & 0.54 & 0.22 & \pm & 0.01 & & & & \\
\hline & 5.2 & $1.0 \mathrm{E}-01$ & 0.20 & 0.08 & 0.00 & 0.86 & 0.10 & \pm & 0.02 & 0.00 & \pm & 0.04 & 0.02 \\
\hline & 5.2 & $5.1 \mathrm{E}-02$ & 0.12 & 0.06 & 0.01 & 0.88 & 0.12 & \pm & 0.05 & & & & \\
\hline & 5.2 & $9.9 \mathrm{E}-03$ & 0.04 & 0.03 & 0.03 & 0.90 & 0.14 & \pm & 0.03 & & & & \\
\hline & 5.1 & $5.3 \mathrm{E}-03$ & 0.02 & 0.02 & 0.05 & 0.88 & 0.19 & \pm & 0.04 & & & & \\
\hline & 5.2 & $9.5 \mathrm{E}-04$ & 0.01 & 0.01 & 0.22 & 0.75 & n.d. & & & & & & \\
\hline
\end{tabular}




\subsection{Cd isotope fractionation during complexation with $\mathrm{HA}$}

The amount of Cd complexed with HA ranged from 25 to $99 \%$ of total Cd in solution (Table 1).

After experiments, the $\delta^{114 / 110} \mathrm{Cd}$ values in solution varied from $0.02 \pm 0.02 \%$ o to $0.22 \pm 0.01 \%$, showing preferentially enrichment in light $\mathrm{Cd}$ isotopes in the complexed form. The kinetic experiments demonstrated that the $\mathrm{Cd}$ isotopic composition was constant throughout the experiment at high ionic strength and that a plateau was rapidly reached after 5 hours at low ionic strength (Fig. S5). Therefore, we can assume that $\mathrm{Cd}$ complexation with $\mathrm{HA}$ reached isotopic equilibrium in the experimental conditions (Fig. 3). The overall $\mathrm{Cd}$ isotope fractionation was defined as $\Delta \Delta^{114 / 110} \mathrm{Cd}_{\mathrm{HA}-\mathrm{Cd}(\mathrm{aq})}$ of $-0.15 \pm 0.01 \%$. Oppositely, previous research on the complexation of other metals belonging to the first raw transition

$267(\mathrm{Cu}, \mathrm{Fe}$, and $\mathrm{Zn})$ showed an enrichment in heavy isotopes bound to HA. These observations were attributed to their stronger binding in organocomplexes than in aqueous solution at equilibrium. ${ }^{67-70}$ Cadmium does not undergo natural redox reactions in such settings, leading us to hypothesize that the isotope fractionation was driven by differences in $\mathrm{Cd}$ coordination chemistry between the dissolved species and the complexed species. In our case, $\mathrm{Cd}$ complexation is driven by carboxylic sites and the electrostatic attractions, which may cause different $\mathrm{Cd}$ isotope fractionations as demonstrated for $\mathrm{Cu}$ with $\mathrm{HA}^{69}$, and in other systems for $\mathrm{Zn} .^{71,72}$ conditions, which included: (i) $\mathrm{pH}$ variations from 4 to 6 , (ii) ionic strengths variations from $10^{-3} \mathrm{~mol} \mathrm{~L}^{-1}$ to $10^{-1} \mathrm{~mol} \mathrm{~L}^{-1}$, and (iii) $\mathrm{Cd}$ concentrations in solution varying from $10^{-6} \mathrm{~mol} \mathrm{~L}^{-1}$ to $10^{-4} \mathrm{~mol} \mathrm{~L}^{-1}$. By including all of these conditions, we had enough controlled data to determine Cd isotope fractionation

278 associated with its complexation with carboxylic groups $\left(\Delta^{114 / 110} \mathrm{Cd}_{(\mathrm{COO}-\mathrm{Cd})-\mathrm{Cd}(\mathrm{aq})}\right)$ and that of the 279 electrostatic attractions $\left(\Delta^{114 / 110} \mathrm{Cd}_{(\mathrm{Cd} 2+\mathrm{D})-\mathrm{Cd}(\mathrm{aq})}\right)$. 


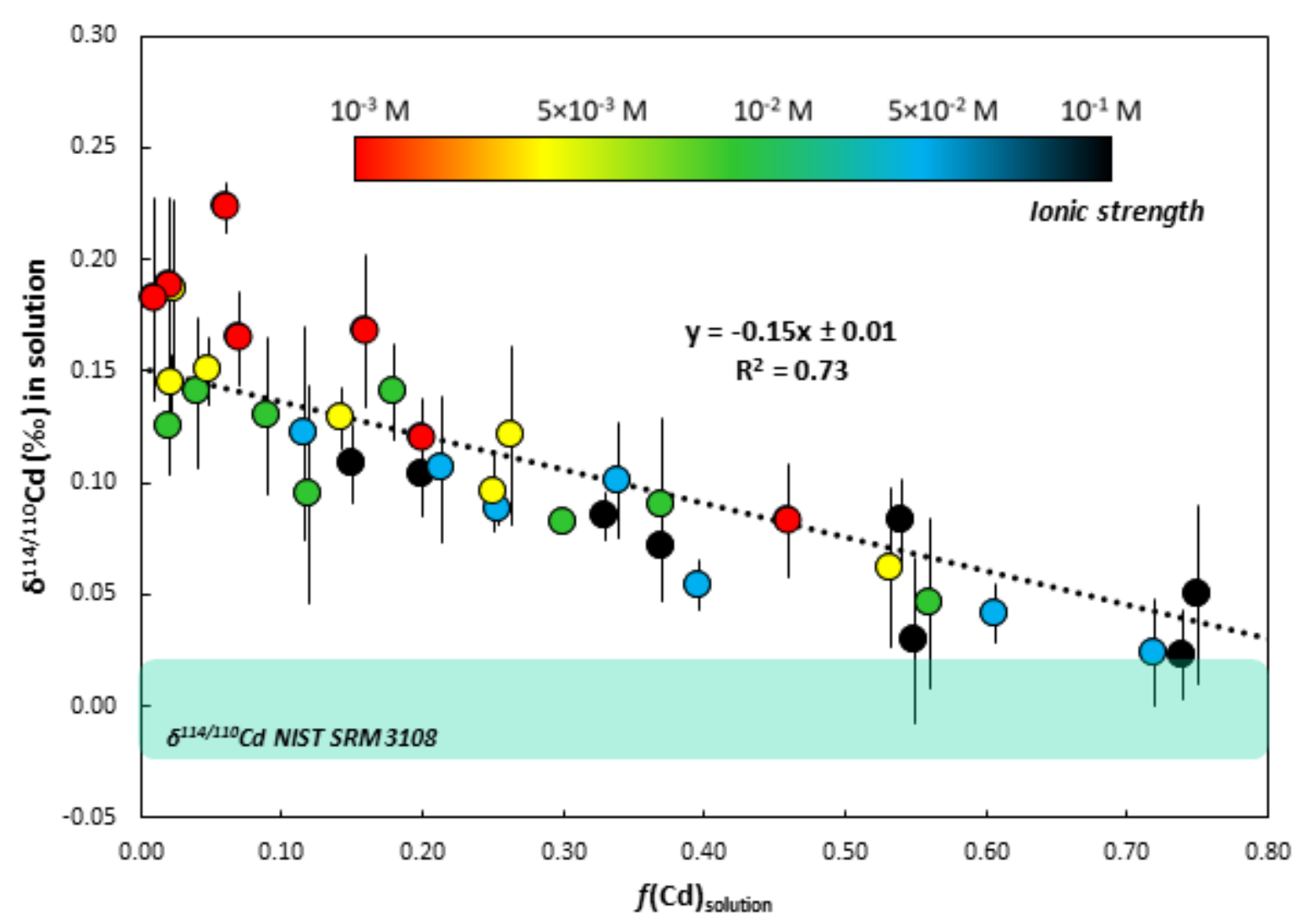

281

282 Figure 3: $\delta^{114 / 110} \mathrm{Cd}$ values (\%o) in solution as a function of the remaining $\mathrm{Cd}$ in solution $(\mathrm{f}(\mathrm{Cd}))$ at 283 different ionic strengths and Cd concentrations $\left(10^{-6} \mathrm{~mol} \mathrm{~L}^{-1}, 10^{-5} \mathrm{~mol} \mathrm{~L}^{-1}\right.$ and $\left.10^{-4} \mathrm{~mol} \mathrm{~L}^{-1}\right)$ after $24 \mathrm{~h}$ of 284 equilibration. Error bars on the y axis refer to 2SD. The graphical estimation gives an overall $\Delta^{114 / 110} \mathrm{Cd}_{\mathrm{HA}}$ $285 \mathrm{Cd}(\mathrm{aq})=-0.15 \pm 0.01 \%$ for the samples, with a linear regression set to $0.00 \%$ or for $\mathrm{f}(\mathrm{Cd})$ value of 1 (black 286 dashed line $)$. The slope uncertainty $( \pm 0.01)$ was determined by the least-squares method. The green 287 shading shows the isotopic range of the bulk starting composition (NIST SRM 3108).

\subsubsection{Specific Cd complexation: carboxylic sites}

The proportion of $\mathrm{Cd}$ complexed with carboxylic sites was determined based on the NICA290 Donnan thermodynamic modeling (Table 1). At high ionic strengths, Cd complexation was primarily dependent on the carboxylic groups $\left(\mathrm{Cd}^{2+}{ }_{\mathrm{D}}\right.$ lower than $3 \%$ of the total $\mathrm{Cd}$ and a ratio $\mathrm{Cd}^{2+}{ }_{\mathrm{D}} / \mathrm{COO}-\mathrm{Cd}$ lower than 0.07 (16 samples). In these conditions, fifteen $\delta^{114 / 110} \mathrm{Cd}$ values in solution were related to $\mathrm{Cd}$ complexation with the carboxylic sites, which represents a preferential enrichment in light isotopes bound to HA following a linear regression (slope: $-0.13 \pm 0.01, \mathrm{R}^{2}=0.80$, Fig. S6). Therefore, the $\Delta^{114 / 110} \mathrm{Cd}_{(\mathrm{COO}-}$ 

Cd(aq) can be calculated with Eq. 2 and 3

$$
\Delta^{114 / 100} \mathrm{Cd}_{\text {final solution-starting solution }}=\delta^{114 / 110} \mathrm{Cd}_{\text {final solution }}-\delta^{114 / 110} \mathrm{Cd}_{\text {starting solution }}
$$

$$
\Delta^{114 / 110} \mathrm{Cd}_{(\mathrm{COO}-\mathrm{Cd})-\mathrm{Cd}(\mathrm{aq})}=-\Delta^{114 / 110} \mathrm{Cd}_{\text {final solution-starting solution } / \%(\mathrm{COO}-\mathrm{Cd})} \times 100
$$

where $\delta^{114} \mathrm{Cd}_{\text {starting solution }}$ is the measured isotope composition of the starting solution. The $\delta^{114} \mathrm{Cd}_{\text {final solution }}$ is

Cd) is the percentage of the Cd complexed with carboxylic groups. The calculation resulted in a mean $\Delta^{114 / 110} \mathrm{Cd}_{(\mathrm{COO}-\mathrm{Cd})-\mathrm{Cd}(\mathrm{aq})}$ value of $-0.12 \pm 0.03 \%$ o $(2 \mathrm{SD}, \mathrm{n}=16)$. the dominant species of dissolved Cd likely have more stable bonds than those in the complexed form. ${ }^{73,74}$ The calculated Cd-O distances for the most common aqueous form $\left(\mathrm{Cd}\left(\mathrm{H}_{2} \mathrm{O}\right)_{6}{ }^{2+}\right)$, either using the density functional theory, ${ }^{75}$ X-ray diffraction, ${ }^{76}$ or RHF/DZP, ${ }^{77}$ range from 2.29 to $2.34 \AA$. Moreover, the Cd-O distances in perchlorate or nitrate solution vary from 2.28 to $2.31 \AA$ with an octahedral geometry and depend on the thermal effect during XAS measurements. ${ }^{76,78-81}$ In our study, the Cd K-edge EXAFS spectra for Cd bound to HA were successfully fitted with first shell coordination of the Cd complexed to HA with an average Cd-O length of $2.29 \AA$ (Fig. S7). Therefore, based on the numerous studies dealing with $\mathrm{Cd}$ in solution, we agree that a slight change of the $\mathrm{Cd}-\mathrm{O}$ first coordination does not permit to confirm that carboxylic groups might express longer and thus weaker bonds than in an aqueous solution. According to Koopal et al. ${ }^{47}$, the thermodynamic parameter " $\mathrm{nCd} / \mathrm{nH}^{\prime}$ ' is interpreted as the stoichiometry of the binding reaction (Table S1). The ratio of 0.9 indicates that the average stoichiometry of $\mathrm{Cd}$ binding with carboxylic groups ${ }^{82,83}$ (with respect to the proton reaction) is mainly monodentate.

316 Therefore, the obtained value $(2.29 \AA)$, which represents the average value of six Cd-O in the first $\mathrm{Cd}$ 317 coordination shell, does not differ from the established Cd-O lengths obtained from $\mathrm{Cd}$ solution 318 species. $^{76,78-81}$ In contrast, S ligands leading to significant coordination changes ${ }^{84,85}$ induce an apparent $\mathrm{Cd}$ 
319 isotope fractionation. ${ }^{81,86}$ As a consequence, the coordination of carboxylic groups to Cd in monodentate 320 fashion led to similar bond distances to water oxygens than in solution. Therefore, a significant isotopic 321 shift would be observed as a result of a bidentate or multidentate Cd complex. Based on the fact that bond 322 strength is related to bond length ${ }^{87,88}$, the preferential presence of heavier $\mathrm{Cd}$ isotopes in the solution 323 cannot be explained only by their smaller Cd-O length than those bound to HA.

Monodentate binding to negatively-charged oxygen donor atoms (phenolic and carboxylic functional groups) and the associated linear free energy relationships (LFER) for metal-ligand complexation led to a different behavior for Cd than for metals of the first transition raw. ${ }^{89}$ Contrary to the metals from the first raw transition, $\mathrm{Cd}^{2+}$ may be subjected to a larger extent to outer-sphere complex prior formation with a ligand in an aqueous solution. ${ }^{90,91}$ Indeed, Cd-ligand $\left(\mathrm{L}^{-}\right)$overall complexation can be described by the following two equilibrium reactions:

$$
\left[\mathrm{Cd}\left(\mathrm{H}_{2} \mathrm{O}\right)_{\mathrm{n}}\right]^{\mathrm{Z}+}+\mathrm{L}^{-} \rightleftharpoons\left[\mathrm{Cd}\left(\mathrm{H}_{2} \mathrm{O}\right)_{\mathrm{n}} \cdots \mathrm{L}\right]^{(\mathrm{Z}-1)+}
$$

$$
\left[\mathrm{Cd}\left(\mathrm{H}_{2} \mathrm{O}\right)_{\mathrm{n}} \cdots \mathrm{L}\right]^{(\mathrm{Z}-1)+} \rightleftharpoons\left[\mathrm{Cd}\left(\mathrm{H}_{2} \mathrm{O}\right)_{\mathrm{n}-1} \mathrm{~L}\right]^{(\mathrm{Z}-1)+}+\mathrm{H}_{2} \mathrm{O}
$$

where $\left[\mathrm{Cd}\left(\mathrm{H}_{2} \mathrm{O}\right)_{\mathrm{n}} \cdot \cdots \mathrm{L}\right]^{(\mathrm{Z}-1)+}$ denotes an outer-sphere complex, in which the ligand forms hydrogenbonds with water molecules in the first coordination sphere of $\mathrm{Cd}^{2+}$, and $\left[\mathrm{Cd}\left(\mathrm{H}_{2} \mathrm{O}\right)_{\mathrm{n}-1} \mathrm{~L}\right]^{(\mathrm{Z}-1)+}$ is the inner334 sphere complex in which one water molecule is replaced by the ligand in the first coordination sphere of $335 \mathrm{Cd}^{2+}$. Therefore, $\mathrm{Cd}$ bound to carboxylic groups includes $\left[\mathrm{Cd}\left(\mathrm{H}_{2} \mathrm{O}\right)_{\mathrm{n}-1} \mathrm{~L}\right]^{(\mathrm{Z}-1)+}$ and $\left[\mathrm{Cd}\left(\mathrm{H}_{2} \mathrm{O}\right)_{\mathrm{n}} \cdot \cdots \mathrm{L}\right]^{(\mathrm{Z}-1)+}$.

$337\left(\beta_{114-110}\right)$ of the $\mathrm{Cd}$ hydration complexes increased with the increase of the number of water molecules, 338 suggesting that the change in the hydration complexes $(4,5$, or 6$)$ may be a significant factor for isotope 339 fractionation in solution. ${ }^{75}$ The isotopic offsets in $\delta^{114 / 110} \mathrm{Cd}\left(\Delta^{114 / 110} \mathrm{Cd}_{\text {hydration complexes }}\right)$ can be estimated 340 using the subtraction of one RPFR from another ${ }^{75}$ (Eq. 6).

$$
\Delta^{114 / 110} \mathrm{Cd}_{\text {hydration complexes }}=\delta^{114 / 110} \mathrm{Cd}\left(\mathrm{H}_{2} \mathrm{O}\right)_{\mathrm{n}-1}-\delta^{114 / 110} \mathrm{Cd}\left(\mathrm{H}_{2} \mathrm{O}\right)_{\mathrm{n}}=10^{3} \ln \beta_{114-110} \mathrm{Cd}\left(\mathrm{H}_{2} \mathrm{O}\right)_{\mathrm{n}-1}-10^{3} \ln \beta_{114-110} \mathrm{Cd}\left(\mathrm{H}_{2} \mathrm{O}\right)_{\mathrm{n}}
$$


The isotopic Cd shift is more pronounced at low temperatures. At $25^{\circ} \mathrm{C}$, the RPFR exhibited 344 2.299, 2.261, and 2.167 for $\mathrm{Cd}\left(\mathrm{H}_{2} \mathrm{O}\right)_{6}{ }^{2+}, \mathrm{Cd}\left(\mathrm{H}_{2} \mathrm{O}\right)_{5}{ }^{2+}, \mathrm{Cd}\left(\mathrm{H}_{2} \mathrm{O}\right)_{4}{ }^{2+}$, respectively. ${ }^{75}$ These results 345 demonstrated that the lighter $\mathrm{Cd}$ isotopes were less stable and thus more susceptible to release a water 346 molecule (inner-sphere complex) leading to the preferential enrichment of lighter Cd isotopes in the HA 347 fraction. Moreover, X-ray absorption spectroscopy (XAS) studies on Cd coordination in solution revealed 348 that $\mathrm{Cd}^{2+}$ could primarily occur as a $\mathrm{Cd}\left(\mathrm{H}_{2} \mathrm{O}\right)_{7}{ }^{2+}$ aqueous complex. ${ }^{92-94}$ Therefore, Cd hydration complex 349 in the aqueous solution is crucial in deciphering the isotope fractionation during its complexation and for 350 Cd isotope systematics in environmental studies in general.

\section{$351 \quad 3.3 .2$. Non-specific Cd binding: electrostatic attractions}

352 In addition to the role of carboxylic groups in $\mathrm{Cd}$ complexation, the electrostatic attractions also 353 played a major role in the total Cd complexation with HA, especially at low ionic strengths and low $\mathrm{pH}$ 354 values (Fig. 2, S3, and S4). Cadmium isotope fractionation plotted as a function of the Cd/Na molar ratio 355 in solution followed a logarithmic regression exhibiting slopes increasing from 0.02 to 0.09 with 356 decreasing $\mathrm{Cd} / \mathrm{Na}$ molar ratio, with the $\mathrm{R}^{2}$ factor ranging from 0.66 to 0.99 (Fig. 4). 


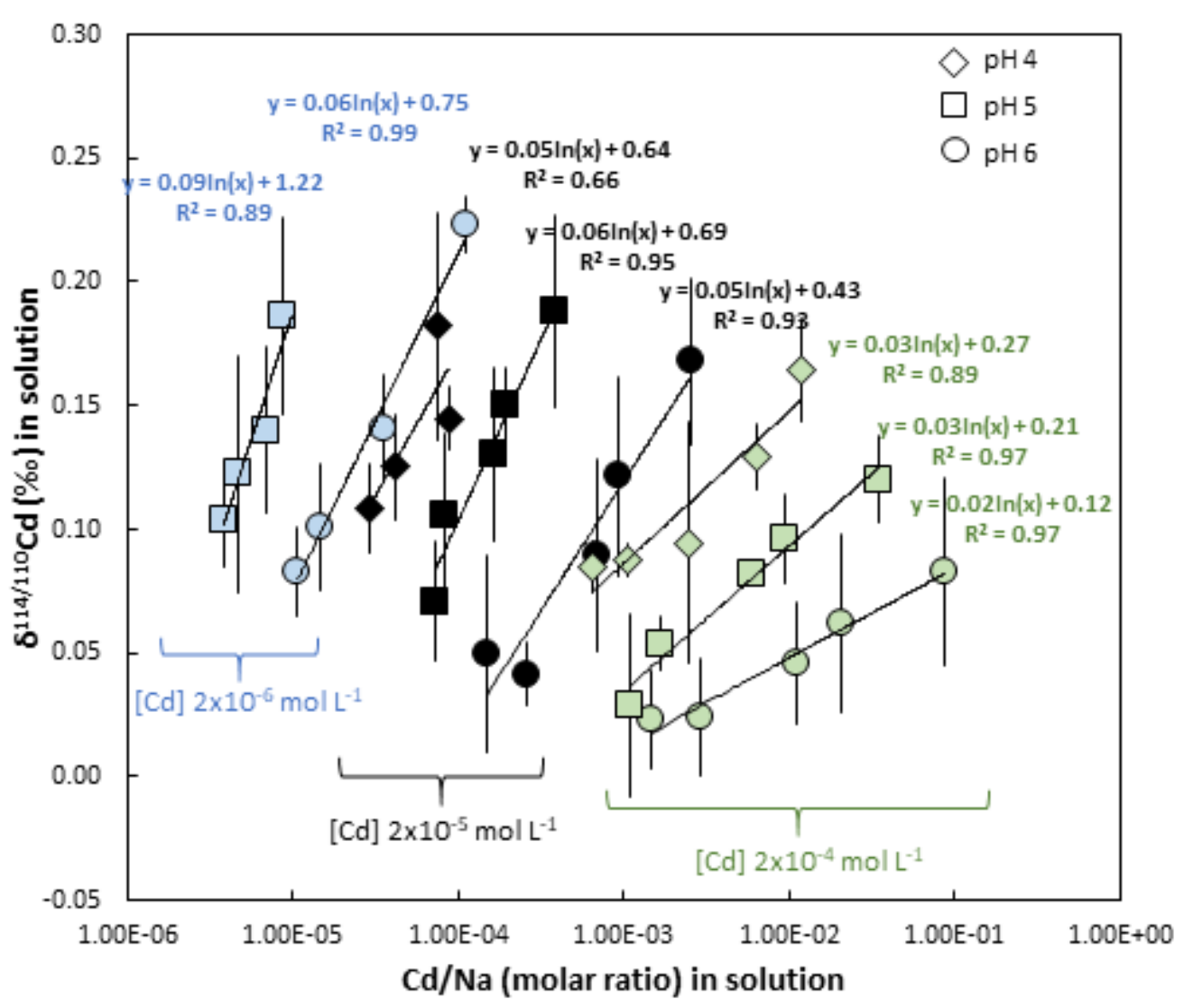

358 Figure 4: Cadmium isotopic composition $\left(\delta^{114 / 110} \mathrm{Cd}\right.$ expressed in \%o) in solution as a function of $\mathrm{Cd} / \mathrm{Na}$ 359 (molar ratio) in solution at the beginning of the experiment. At each $\mathrm{pH}$ and each [Cd] in solution, the 360 experimental data follows a logarithmic regression expressed by the equation and the $\mathrm{R}^{2}$ factor. The error 361 bars represent the analytical error (2SD).

362 Prior to this study, the exact influence of non-specific binding induced by electrostatic attractions 363 on metal isotope fractionation has never been studied during metal complexation with HA. The 364 complexation of $\mathrm{Zn}$ with $\mathrm{HA}$, despite a low ionic strength $\left(2 \times 10^{-3} \mathrm{~mol} \mathrm{~L}^{-1}\right)$, has shown that electrostatic 365 attractions represent only a small proportion of $\mathrm{Zn}$ bound to HA and therefore not capable to cause a 366 measurable isotope fractionation. ${ }^{68}$ The same observation has been noted for $\mathrm{Cu}$ at high ionic strength $\left(10^{-}\right.$ $\left.367{ }^{1} \mathrm{~mol} \mathrm{~L}^{-1}\right)$, where electrostatically adsorbed $\mathrm{Cu}$ represented only a minor part $(0.1-1 \%)$ of total $\mathrm{Cu}$ bound 368 to HA. ${ }^{69}$ However, our results showed that the proportion of $\mathrm{Cd}$ complexed by electrostatic attractions 369 reached up to $50 \%$ of the total Cd, corresponding to $60 \%$ of the total complexed Cd (Fig. 2). Based on the 370 Cd isotopic composition measured in solution and the $\mathrm{Cd}$ isotope fractionation attributed to the carboxylic 

coefficient induced by electrostatic attractions with Eq. 7 and 8:

$$
\begin{gathered}
\Delta^{114 / 110} \mathrm{Cd}_{\mathrm{x}-\mathrm{y}}=\delta^{114 / 110} \mathrm{Cd}_{\mathrm{x}}-\delta^{114 / 110} \mathrm{Cd}_{\mathrm{y}}=1,000 \ln \left(\alpha_{\mathrm{x}-\mathrm{y}}\right) \\
\alpha_{\mathrm{x}-\mathrm{y}}=\frac{\delta^{114 / 110} \mathrm{Cd}_{\mathrm{x}}+1,000}{\delta^{114 / 110} \mathrm{Cd}_{\mathrm{y}}-1,000}
\end{gathered}
$$

where $\mathrm{x}$ represents $\mathrm{Cd}^{2+}{ }_{\text {aq }}$ and $\mathrm{y}$ represents $\mathrm{COO}-\mathrm{Cd}$ and $\mathrm{Cd}^{2+}{ }_{\mathrm{D}}$; with their associated fractionation coefficient $\alpha_{(\mathrm{COO}-\mathrm{Cd})}$ and $\left.\alpha_{(\mathrm{Cd}}^{2+} \mathrm{D}\right)$, respectively. According to our previous results, we defined $\alpha_{(\mathrm{COO}-\mathrm{Cd})}$ as 1.00013 and the $\left.\alpha_{(\mathrm{Cd}}{ }^{2+} \mathrm{D}\right)$ was determined by the least-squares method to model the $\delta^{114 / 110} \mathrm{Cd}$ values in solution with Eq 9:

$$
\delta^{114 / 110} \mathrm{Cd}_{\text {modeled solution }}=-1,000 f\left[\frac{\mathrm{P}_{\mathrm{COO}-\mathrm{Cd}} \times\left(\alpha_{(\mathrm{COO}-\mathrm{Cd})}-1\right)}{1-f+\left(f \times \alpha_{(\mathrm{COO}-\mathrm{Cd})}\right)}+\frac{\mathrm{P}_{\mathrm{Cd}_{\mathrm{D}}^{2+}} \times\left(\alpha_{\left(\mathrm{Cd}_{\mathrm{D}}^{2+}\right)}-1\right)}{1-f+\left(f \times \alpha_{\left(\mathrm{Cd}_{\mathrm{D}}^{2+}\right)}\right)}\right]
$$

where $f$ is the total fraction complexed with $\mathrm{HA}, \mathrm{P}_{\mathrm{COO}-\mathrm{Cd}}$ and $\mathrm{P}_{\mathrm{Cd}}{ }^{2+} \mathrm{D}$ are the proportions of each site in total complexed Cd, and $\alpha_{(\mathrm{COO}-\mathrm{Cd})}$ and $\alpha_{(\mathrm{Cd}}^{2+}{ }_{\mathrm{D})}$ are their respective fractionation coefficients.

Therefore, the best agreement between the measured $\delta^{114 / 110} \mathrm{Cd}$ values in solution and modeled

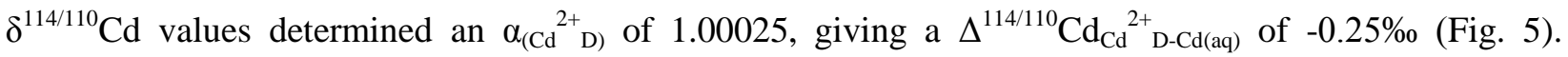
Surprisingly, the electrostatic attractions induced more extensive isotope fractionation than $\mathrm{Cd}$ complexation with carboxylic groups. However, when Cd complexation with carboxylic groups led to an inner-sphere complex, the electrostatic attractions were likely caused by a dipole-ion attraction between the $\mathrm{Cd}$ cation and the dipole of the oxygen from the $\mathrm{OH}$ responsible for an outer-sphere interaction. (complexation or hydration complexes) or Cd-HA bond lengths will not be modified relatively to the aqueous form of $\mathrm{Cd}$. Therefore, there is no reason that such process induces $\mathrm{Cd}$ isotope fractionation. We also show the modeled $\delta^{114 / 110} \mathrm{Cd}$ values in solution with a value of $\left.\alpha_{(\mathrm{Cd}}{ }^{2+} \mathrm{D}\right)$ set to 1 , signifying that electrostatic attractions do not produce measurable $\mathrm{Cd}$ isotope fractionation (Fig. S8), which led to an underestimation of the measured $\delta^{114 / 110} \mathrm{Cd}$ values at lower ionic strengths. 


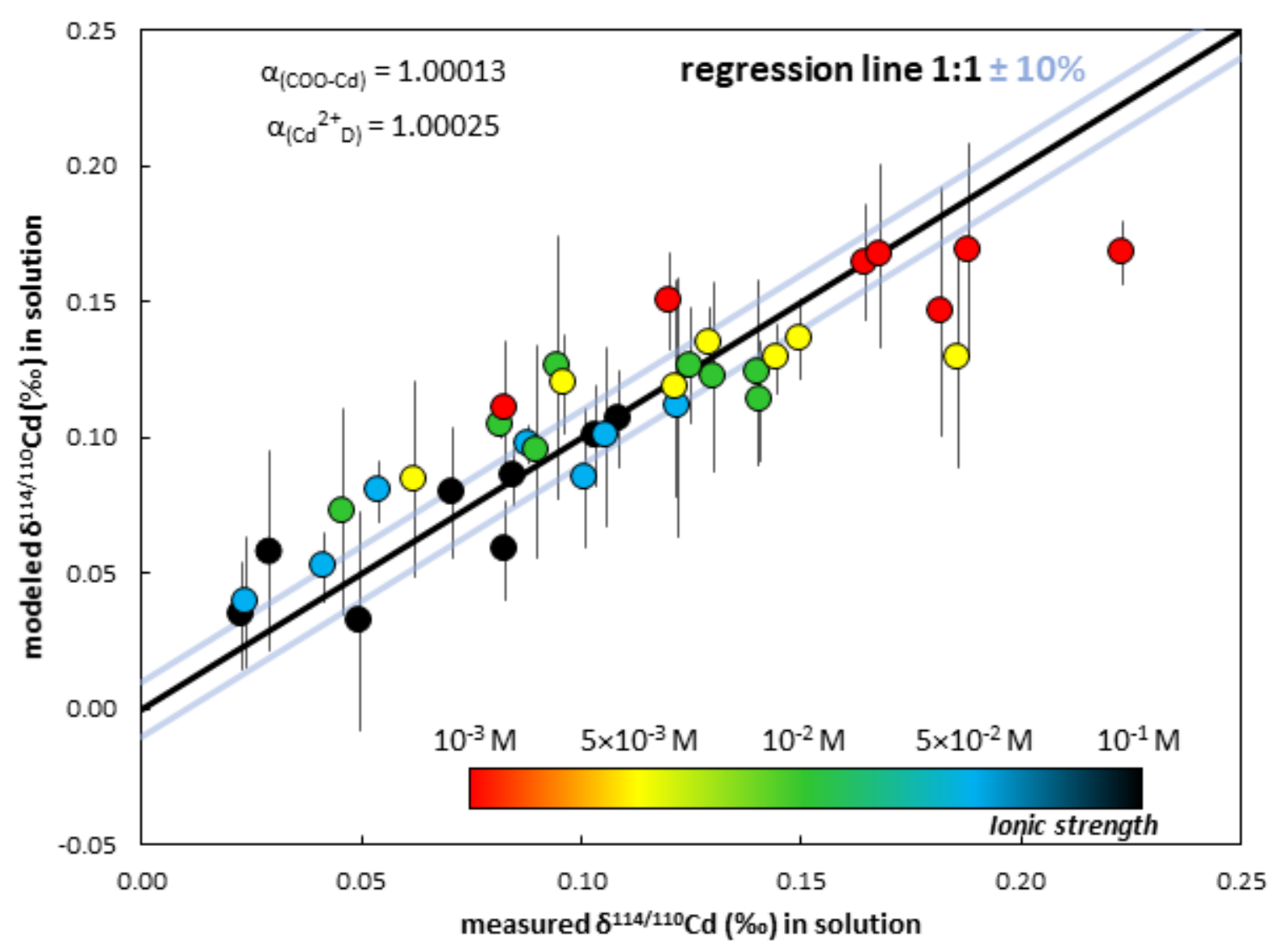

395 Figure 5: Comparison between measured $\delta^{114 / 110} \mathrm{Cd}$ in solution and modeled $\delta^{114 / 110} \mathrm{Cd}$ through isotopic mass balance calculation (Eq. 8) for $\alpha_{(\mathrm{COO}-\mathrm{Cd})}$ of 1.00013. and $\left.\alpha_{(\mathrm{Cd}}{ }^{2+} \mathrm{D}\right)$ of 1.00025 . The $\left.\alpha_{(\mathrm{Cd}}{ }^{2+} \mathrm{D}\right)$ was determined by the least-squares method. The black line represents the linear regression 1:1 with a range of $10 \%$ (grey lines). The error bars represent the analytical error (2SD).

Therefore, a $\Delta^{114 / 110} \mathrm{Cd}_{\mathrm{Cd}}{ }^{2+} \mathrm{D}$-Cd(aq) of $-0.25 \%$ has to be applied to $\mathrm{Cd}$ isotopes fractionation during

400 the complexation with HA. Humic acids are large and negatively charged polyelectrolytes, which results

401 in the accumulation of cations in the vicinity of HA binding sites, leading to different chemical conditions

402 between the solution and the vicinity of HA. Electrostatic models ${ }^{95}$ (Nica Donnan, Donnan-EV, Donnan-

403 EDL model, etc.) aim at converting the dissolved cation concentration in the bulk solution ([C $\left.]_{\mathrm{i}}\right)$ to a local

404 dissolved cation concentration $\left([\mathrm{C}]_{\mathrm{loc}, \mathrm{i}}\right.$ ) that occurs adjacent to the HA site, calculated according to the

405 Boltzmann's law with Eq. 10: 
407 where $\mathrm{z}\left(\mathrm{Cd}^{2+}\right)$ is the valence of $\mathrm{Cd}, \mathrm{F}$ is the Faraday constant, $\Psi$ is the electrostatic potential of $\mathrm{HA}$ 408 particles, $\mathrm{R}$ is the gas constant, and $\mathrm{T}$ is the absolute temperature. This effect is calculated using the 409 Boltzmann factor (Bf) with Eq. 11:

$$
B f=\frac{[\mathrm{C}]_{\mathrm{Cd}_{\mathrm{D}}^{2+}}}{[\mathrm{C}]_{\mathrm{Cd}_{\mathrm{aq}}^{2+}}}
$$

411 The $\Delta^{114 / 110} \mathrm{Cd}_{\mathrm{HA}-\mathrm{Cd}(\mathrm{aq})}$ calculated (Eq. 12), based on measured $\delta^{114 / 110} \mathrm{Cd}$ value and the verified 412 isotopic mass balance (Table 1), was expressed as a function of the Bf (Fig. 6).

$$
\Delta^{114 / 110} \mathrm{Cd}_{\text {HA-Cd(aq) calculated }}=\left(\delta^{114 / 110} \mathrm{Cd}_{\text {initial }}-f\left(C d_{a q}\right) \times \delta^{114 / 110} \mathrm{Cd}_{\text {solution }}\right) /\left(1-f\left(C d_{a q}\right)\right)-\left(\delta^{114 / 110} \mathrm{Cd}_{\text {solution }}\right)
$$

415 where $f\left(C d_{a q}\right)$ is the proportion of $\mathrm{Cd}$ in the aqueous form in solution and $\delta^{114 / 110} \mathrm{Cd}_{\text {initial }}$ is set to $0 \%$.

416 At low $\mathrm{Bf}$, isotope fractionation is limited, and the $\Delta \Delta^{114 / 110} \mathrm{Cd}_{\mathrm{HA}-\mathrm{Cd}(\mathrm{aq})}$ is controlled by carboxylic 417 complexation. However, at high $\mathrm{Bf}$, the strongest isotope fractionation is observed, related to the non418 specific $\mathrm{Cd}$ binding during electrostatic attractions. As a result, these must play a significant role in Cd 419 isotope fractionation during complexation with HA. As previously observed for $\mathrm{Zn}$ sorption onto 420 kaolinite, ${ }^{72}$ the mechanism leading to preferential lighter $\mathrm{Cd}$ isotope enrichment during outer-sphere 421 complexation formation via electrostatic attractions remains unclear and additional studies are required to 422 explain the effect of electrostatic attractions on metal isotope fractionation.

423 In general, $\mathrm{Cd}$ isotope fractionation is controlled by $\mathrm{pH}$ and ionic strength and occurs throughout 424 specific complexation processes with the carboxylic sites and non-specific Cd binding induced by 425 electrostatic attractions. Based on our large experimental dataset, the overall Cd isotope fractionation due 426 to Cd complexation with HA can be set for future studies as a $\Delta^{114 / 110} \mathrm{Cd}_{\mathrm{HA}-\mathrm{Cd}(\mathrm{aq})}$ of $-0.15 \pm 0.01 \%$. 


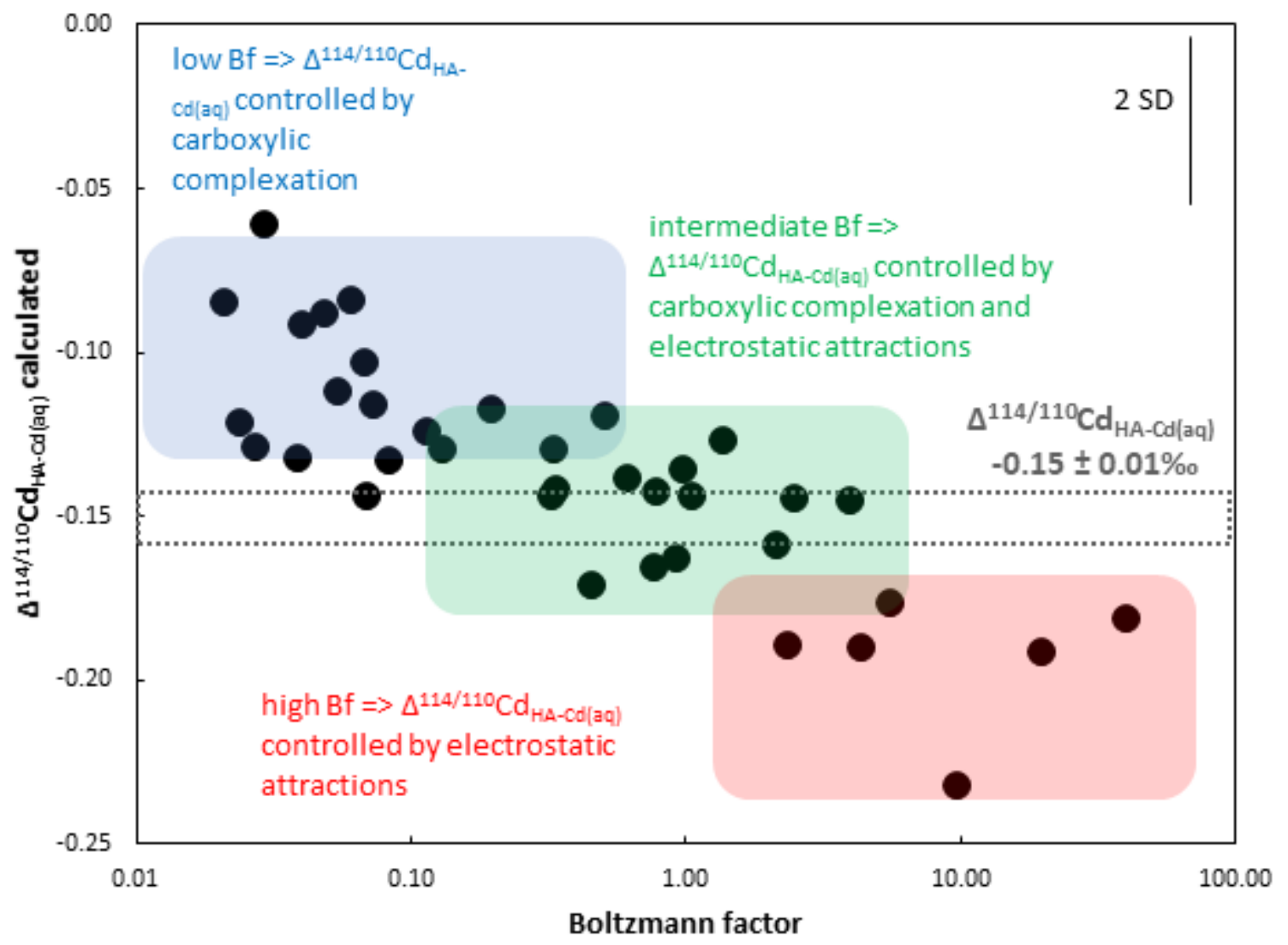

428 Figure 6: $\Delta^{114 / 110} \mathrm{Cd}_{\mathrm{HA}-\mathrm{Cd}(\mathrm{aq})}$ calculated as a function of the Boltzmann factor (Bf). The error bar represents 429 the highest analytical error observed for one measured $\delta{ }^{114 / 110} \mathrm{Cd}$ value (2SD). The grey rectangle 430 represents the overall $\mathrm{Cd}$ isotope fractionation due to $\mathrm{Cd}$ complexation with $\mathrm{HA}$ as $\Delta^{114 / 110} \mathrm{Cd}_{\mathrm{HA}-\mathrm{Cd}(\mathrm{aq})}=$ $431 \quad 0.15 \pm 0.01 \%$.

\section{4. Environmental implications}

Our study is an important contribution to Cd isotope systematics focusing on Cd complexation

434 with HA, an important constituent in soils, sediments and waters. Information on Cd isotope fractionation

435 after complexation with natural organic matter is crucial to fully understand the biogeochemical processes

436 in the Cd-soil-aqueous solution-plant continuum and for contamination tracing. The introduction of $\mathrm{Cd}$ to

437 the soil environment and its initial solubilization is followed by numerous biogeochemical reactions with

438 soil components. Modeling Cd speciation in soil solution revealed that dissolved Cd is present either

439 bound to dissolved organic matter $(\mathrm{DOM})$ or as free $\mathrm{Cd}^{2+} \cdot{ }^{86}$ Based on our data on Cd isotope fractionation 
440 after complexation with the carboxylic sites and bound to HA by electrostatic attractions, we show that 441 free $\mathrm{Cd}^{2+}$, which is the main form taken up by the plants, ${ }^{96}$ should be preferentially enriched with the 442 heavier isotopes compared to $\mathrm{Cd}$ bound to soil organic matter, as assumed in a previous study. ${ }^{86}$ These 443 findings are in accordance with the heavier $\mathrm{Cd}$ isotope pool available for crops and $\mathrm{Cd}$ hyper444 accumulating plant species. ${ }^{8-11,86}$ However, when environmental factors change, e.g., $\mathrm{pH}$ and Eh due to 445 flooding, contaminants input, soil organic matter quantity and quality, ionic strength of the soil solution, 446 etc., changes of $\mathrm{Cd}$ sorption/desorption occurs as a result of the competition of negatively charged sites, 447 and the $\mathrm{Cd}$ isotope composition may thus be strongly modified. In order to completely understand $\mathrm{Cd}$ 448 behavior in the soil environment, studies involving other soil constituents, and their affinity to Cd, are 449 required. Moreover, a comparison of our study with HA analogs (plants, phytoplankton, diatoms, etc.) 450 would allow explaining simple complexation mechanisms, although we are aware of the fact that limiting 451 the conclusions to these simple processes might be a simplification. determined by Cd K-edge EXAFS spectroscopy. Additionally, Ueno et al. ${ }^{99}$ and Tian et al. ${ }^{100}$ found that in 454 Cd hyperaccumulators leaves, $\mathrm{Cd}$ was present in an octahedral coordination with O ligands, possibly due 455 to the presence of malate and citrate. Therefore, the complexation of $\mathrm{Cd}$ with malate and citrate in the 456 leaves, i.e., carboxylic ligands, might be responsible for the preferential enrichment in light isotopes. 457 Recent development of Cd isotope measurements in the ocean provides new clues for identifying the key 458 mechanisms controlling the Cd biogeochemical cycle in surface ocean. While the effect of uptake by 459 phytoplankton on $\delta^{114 / 110} \mathrm{Cd}$ signatures has been shown in nutrient repleted regions, ${ }^{4,101}$ the impact of 460 organic complexation is still debated, namely for its buffering effect on the $\delta^{114 / 110} \mathrm{Cd}$ measured in 461 nutrient-depleted waters. ${ }^{102}$ In surface seawater, Cd aqueous speciation is dominated by Cd-organic 462 complexes. ${ }^{103-105}$ Thus, the dissolved $\delta^{114 / 110} \mathrm{Cd}$ is similar to those complexes. Previous research has shown 463 that $\mathrm{Cd}$ organic complexation only occurs via surface complexation since the $0.5 \mathrm{~mol} \mathrm{~L}^{-1}$ mean ionic 464 strength of seawater prevents any electrostatic attractions. Louis et al. ${ }^{106}$ showed that dissolved organic 465 matter sampled in the Mediterranean Sea off the coast of France is composed of $60 \%$ carboxylic and $40 \%$ 
phenolic sites, in agreement with the overall binding site composition of the HA used in this study. 467 Therefore, based on the relatively small value of $\Delta^{114 / 110} \mathrm{Cd}_{(\mathrm{COO}-\mathrm{Cd})-\mathrm{Cd}(\mathrm{aq})}=-0.13 \%$ o determined in our study, 468 only a minor change of dissolved oceanic $\delta^{114 / 110} \mathrm{Cd}$ can be associated with organic complexation. The 469 isotopic shift is even smaller than the $\mathrm{Cd}$ isotope partitioning between $\mathrm{Cd}$ inorganic species $\left(\Delta^{114 / 110} \mathrm{Cd}\right.$ of $0.3 \%$ for $\left.\mathrm{Cd}^{2+} / \mathrm{CdCl}_{2}\right){ }^{18}$

In addition to organic ligands, phytoplankton-derived debris found as particles in the surface ocean can act as a $\mathrm{Cd}$ sink via surface complexation. After diatom remineralization, Cd adsorption 473 occurring on the remineralization-resistant Dunaliella tertiolecta surface leads to a limited $\Delta^{114 / 110} \mathrm{Cd}$ 474 fractionation of $-0.1 \pm 0.1 \%{ }^{5}$ Furthermore, Pokrovsky et al. ${ }^{107}$ and Gélabert et al. ${ }^{108}$ have shown that 475 carboxyl functional groups are responsible for more than $90 \%$ of total bound $\mathrm{Zn}$ and the behavior of $\mathrm{Cd}$ is 476 similar to $\mathrm{Zn}$ since these two metals share the same geochemical traits. Therefore, our observations of 477 limited $\mathrm{Cd}$ isotope fractionation during complexation with carboxylic groups is totally consistent with 478 previous studies and strengthens the limited impact of $\mathrm{Cd}$ scavenging on the distribution of Cd isotopes 479 during diatom mineralization. in surface oceanic waters is secondary with respect to Cd uptake by phytoplankton, which tends to enrich 482 the dissolved $\delta^{114 / 110} \mathrm{Cd}$ with preferentially heavier isotopes $\left(\Delta^{114 / 110} \mathrm{Cd}_{\text {surface-deepwater }}\right.$ up to $2.5 \%$ o). ${ }^{4,52,101}$ 483 However, in oligotrophic environments, stable and light $\delta^{114 / 110} \mathrm{Cd}$ were measured at picomolar Cd 484 concentrations. ${ }^{102,109}$ As reported before, due to the predominance of the Cd-organic complexes in the 485 dissolved fraction, dissolved $\delta^{114 / 110} \mathrm{Cd}$ is directly driven by the Cd-organic fraction. The absence of 486 heavier $\delta^{114 / 110} \mathrm{Cd}$ linked with $\mathrm{Cd}$ biological uptake in such context indicates a buffering effect of the Cd487 organic complexes in solution as proposed recently by Xie et al. ${ }^{102}$ and Guinoiseau et al. ${ }^{6}$ for the Atlantic 488 Ocean transects. So, even if a small isotope fractionation is observed during Cd organic complexation, the 489 importance of these organic complexes on the Cd oceanic cycle in metal-depleted water masses can be 490 indirectly indicated using $\mathrm{Cd}$ isotopes. 


\section{Acknowledgements}

The authors are thankful for the support from the Czech Science Foundation (18-07585S). The 493 authors also acknowledge Marie Králová, Adéla Š́pková, Andrea Žitková, Aleš Vaněk, and Petra 494 Vokurková for their assistance in the laboratories and chemical measurements. James Tuffano is 495 acknowledged for English editing. The synchrotron session at SOLEIL was partly funded by the European 496 Framework Program for Research and Innovation (CALIPSOplus). The authors thank the SAMBA 497 beamline staff for their support. The authors would also like to thank Stephen J.G. Galer (Max Planck 498 Institute for Chemistry, Mainz-Germany) for his helpful advice regarding the Cd separation protocol and

499 TIMS measurements. Rémi Marsac was supported by the C-FACTOR project funded by ANR (project 500 number ANR-18-CE01-0008). Damien Guinoiseau is financially supported by the ANR RECA (project number ANR-17-CE01-0012). Three reviewers and the editor, Dr. Thomas B. Hofstetter, are 502 acknowledged for their constructive comments and for significantly improving the quality of the 503 manuscript.

\section{Author Contributions}

Cd isotopes determination with contributions of V.C. and Z.V. (Cd separation and TIMS measurements).

R.M. and G.R. performed the modelling and the interpretation. G.R. drafted the manuscript with inputs

508 from all authors with extended participation of D.G., specifically on the ocean discussion part. M.K. was 509 responsible for funding acquisition.

\section{References}

511 1. Rosman, K. J. R. \& De Laeter, J. R. The isotopic composition of cadmium in terrestrial minerals. 512 International Journal of Mass Spectrometry and Ion Physics 16, 385-394 (1975).

513 2. Rosman, K. J. R., De Laeter, J. R. \& Gorton, M. P. Cadmium isotope fractionation in fractions of 514 two H3 chondrites. Earth and Planetary Science Letters 48, 166-170 (1980). 
515 3. Ripperger, S., Rehkämper, M., Porcelli, D. \& Halliday, A. Cadmium isotope fractionation in 516 seawater-A signature of biological activity. Earth and Planetary Science Letters 261, 670-684 $517 \quad$ (2007).

518 4. Abouchami, W. et al. Modulation of the Southern Ocean cadmium isotope signature by ocean 519 circulation and primary productivity. Earth and Planetary Science Letters 305, 83-91 (2011).

520 5. Conway, T. M. \& John, S. G. Biogeochemical cycling of cadmium isotopes along a high-resolution 521 section through the North Atlantic Ocean. Geochimica et Cosmochimica Acta 148, 269-283 (2015).

522 6. Guinoiseau, D. et al. Importance of cadmium sulfides for biogeochemical cycling of Cd and its 523 isotopes in Oxygen Deficient Zones-a case study of the Angola Basin. Global Biogeochemical $524 \quad$ Cycles (2019).

525 7. Wei, R. et al. Fractionation of stable cadmium isotopes in the cadmium tolerant Ricinus communis 526 and hyperaccumulator Solanum nigrum. Scientific reports 6, 24309 (2016).

527 8. Wiggenhauser, M. et al. Cadmium isotope fractionation in soil-wheat systems. Environmental 528 science \& technology 50, 9223-9231 (2016).

529 9. Wiggenhauser, M. et al. Using isotopes to trace freshly applied cadmium through mineral $530 \quad$ phosphorus fertilization in soil-fertilizer-plant systems. Science of the total environment 648, 779786 (2019).

10. Imseng, M. et al. Fate of Cd in agricultural soils: A stable isotope approach to anthropogenic impact, soil formation and soil-plant cycling. Environmental Science \& Technology (2018).

534 11. Zhou, J.-W. et al. Cadmium Isotopic Fractionation in the Soil-Plant System during Repeated Phytoextraction with a Cadmium Hyperaccumulating Plant Species. Environmental Science \& Technology 54, 13598-13609 (2020).

12. Cloquet, C., Carignan, J., Libourel, G., Sterckeman, T. \& Perdrix, E. Tracing source pollution in soils using cadmium and lead isotopes. Environmental science \& technology 40, 2525-2530 (2006). during smelting and refining. Sci. Total Environ. 408, 2357-2368 (2010). 
14. Chrastný, V. et al. Cadmium isotope fractionation within the soil profile complicates source identification in relation to $\mathrm{Pb}-\mathrm{Zn}$ mining and smelting processes. Chemical Geology 405, 1-9 (2015).

15. Martinková, E. et al. Cadmium isotope fractionation of materials derived from various industrial processes. Journal of hazardous materials 302, 114-119 (2016).

16. Wasylenki, L. E., Swihart, J. W. \& Romaniello, S. J. Cadmium isotope fractionation during adsorption to Mn oxyhydroxide at low and high ionic strength. Geochimica et Cosmochimica Acta 140, 212-226 (2014).

17. Horner, T. J., Rickaby, R. E. \& Henderson, G. M. Isotopic fractionation of cadmium into calcite. Earth and Planetary Science Letters 312, 243-253 (2011).

18. Guinoiseau, D., Galer, S. J. \& Abouchami, W. Effect of cadmium sulphide precipitation on the partitioning of $\mathrm{Cd}$ isotopes: Implications for the oceanic Cd cycle. Earth and Planetary Science Letters 498, 300-308 (2018).

19. Xie, X., Yan, L., Li, J., Guan, L. \& Chi, Z. Cadmium isotope fractionation during Cd-calcite coprecipitation: Insight from batch experiment. Science of The Total Environment 143330 (2020).

20. Järup, L. \& Åkesson, A. Current status of cadmium as an environmental health problem. Toxicology and applied pharmacology 238, 201-208 (2009).

21. Järup, L., Berglund, M., Elinder, C. G., Nordberg, G. \& Vanter, M. Health effects of cadmium exposure-a review of the literature and a risk estimate. Scandinavian journal of work, environment \& health 1-51 (1998).

22. Godt, J. et al. The toxicity of cadmium and resulting hazards for human health. Journal of occupational medicine and toxicology 1, 22 (2006).

23. Cullen, J. T. \& Maldonado, M. T. Biogeochemistry of cadmium and its release to the environment. in Cadmium: from toxicity to essentiality 31-62 (Springer, 2013).

24. Nriagu, J. O. Global metal pollution: poisoning the biosphere? Environment: Science and Policy for Sustainable Development 32, 7-33 (1990). 
25. Wedepohl, K. H. The composition of the continental crust. Geochimica et cosmochimica Acta 59, $1217-1232$ (1995).

26. Rudnick, R. L. \& Gao, S. The crust. Treatise on geochemistry. Elsevier Ltd. Oxford 3, 1-64 (2003).

27. Du, H., Peacock, C. L., Chen, W. \& Huang, Q. Binding of Cd by ferrihydrite organo-mineral

29. Kipton, H., Powell, J. \& Town, R. M. Solubility and fractionation of humic acid; effect of pH and

34. Kerndorff, H. \& Schnitzer, M. Sorption of metals on humic acid. Geochimica et Cosmochimica Acta 44, 1701-1708 (1980).

35. Tan, K. H. Environmental soil science. (Marcel Dekker, Inc., 1994). ionic medium. Analytica Chimica Acta 267, 47-54 (1992).

30. Stevenson, F. J. Humus chemistry: genesis, composition, reactions. (John Wiley \& Sons, 1994).

31. Klučáková, M. \& Pekař, M. Solubility and dissociation of lignitic humic acids in water suspension. Colloids and Surfaces A: Physicochemical and Engineering Aspects 252, 157-163 (2005).

32. McKnight, D. M. \& Aiken, G. R. Sources and age of aquatic humus. in Aquatic humic substances 939 (Springer, 1998).

33. Yonebayashi, K. \& Hattori, T. Chemical and biological studies on environmental humic acids: I. Composition of elemental and functional groups of humic acids. Soil Science and Plant Nutrition 34, $571-584(1988)$.

36. Pandey, A. K., Pandey, S. D. \& Misra, V. Stability constants of metal-humic acid complexes and its role in environmental detoxification. Ecotoxicology and environmental safety 47, 195-200 (2000). 
37. Pandey, A. K., Pandey, S. D., Misra, V. \& Viswanathan, P. N. Formation of soluble complexes of metals with humic acid and its environmental significance. Chemistry and Ecology 16, 269-282 (1999).

38. Zeledón- Toruño, Z., Lao- Luque, C. \& Solé- Sardans, M. Nickel and copper removal from aqueous solution by an immature coal (leonardite): effect of $\mathrm{pH}$, contact time and water hardness. Journal of Chemical Technology \& Biotechnology: International Research in Process, Environmental \& Clean Technology 80, 649-656 (2005).

39. Lao, C., Zeledón, Z., Gamisans, X. \& Solé, M. Sorption of Cd (II) and Pb (II) from aqueous solutions by a low-rank coal (leonardite). Separation and purification technology 45, 79-85 (2005).

40. Chammui, Y., Sooksamiti, P., Naksata, W., Thiansem, S. \& Arqueropanyo, O. Removal of arsenic from aqueous solution by adsorption on Leonardite. Chemical Engineering Journal 240, 202-210 (2014).

41. Fowkes, W. W. \& Frost, C. M. Leonardite: a lignite byproduct. vol. 5611 (US Department of the Interior, Bureau of Mines, 1960).

42. Vermeer, A. W. P., Van Riemsdijk, W. H. \& Koopal, L. K. Adsorption of humic acid to mineral particles. 1. Specific and electrostatic interactions. Langmuir 14, 2810-2819 (1998).

43. Marsac, R., Davranche, M., Gruau, G. \& Dia, A. Metal loading effect on rare earth element binding to humic acid: Experimental and modelling evidence. Geochimica et Cosmochimica Acta 74, 1749$1761(2010)$.

44. Gustafsson, J. P. Visual MINTEQ ver. 3.0. http://www2. lwr. kth. se/English/OurSoftware/vminteq/index. htm (2010).

45. Benedetti, M. F. et al. Metal ion binding by natural organic matter: from the model to the field. Geochimica et Cosmochimica Acta 60, 2503-2513 (1996).

46. Benedetti, M. F., Milne, C. J., Kinniburgh, D. G., Van Riemsdijk, W. H. \& Koopal, L. K. Metal ion binding to humic substances: application of the non-ideal competitive adsorption model. Environmental Science \& Technology 29, 446-457 (1995). 
47. Koopal, L. K., Saito, T., Pinheiro, J. P. \& Van Riemsdijk, W. H. Ion binding to natural organic matter: general considerations and the NICA-Donnan model. Colloids and Surfaces A: Physicochemical and Engineering Aspects 265, 40-54 (2005).

48. Milne, C. J., Kinniburgh, D. G. \& Tipping, E. Generic NICA-Donnan model parameters for proton binding by humic substances. Environmental Science \& Technology 35, 2049-2059 (2001).

49. Milne, C. J., Kinniburgh, D. G., Van Riemsdijk, W. H. \& Tipping, E. Generic NICA- Donnan model parameters for metal-ion binding by humic substances. Environmental Science \& Technology 37, 958-971 (2003).

50. Schmitt, A.-D., Galer, S. J. \& Abouchami, W. Mass-dependent cadmium isotopic variations in nature with emphasis on the marine environment. Earth and Planetary Science Letters 277, 262-272 (2009).

51. Schmitt, A.-D., Galer, S. J. \& Abouchami, W. High-precision cadmium stable isotope measurements by double spike thermal ionisation mass spectrometry. Journal of Analytical Atomic Spectrometry 24, 1079-1088 (2009).

52. Abouchami, W. et al. Biogeochemical cycling of cadmium isotopes in the Southern Ocean along the Zero Meridian. Geochimica et Cosmochimica Acta 127, 348-367 (2014).

53. Abouchami, W. et al. A common reference material for cadmium isotope studies-NIST SRM 3108. Geostandards and Geoanalytical Research 37, 5-17 (2013).

54. Li, D., Li, M.-L., Liu, W.-R., Qin, Z.-Z. \& Liu, S.-A. Cadmium isotope ratios of standard solutions and geological reference materials measured by MC- ICP- MS. Geostandards and Geoanalytical Research 42, 593-605 (2018).

55. Liu, M.-S. et al. High- Precision Cd Isotope Measurements of Soil and Rock Reference Materials by MC- ICP- MS with Double Spike Correction. Geostandards and Geoanalytical Research 44, 169$182(2020)$.

56. Tan, D. et al. High-sensitivity determination of Cd isotopes in low-Cd geological samples by double spike MC-ICP-MS. Journal of Analytical Atomic Spectrometry 35, 713-727 (2020). 
57. Ravel, B. \& Newville, M. ATHENA, ARTEMIS, HEPHAESTUS: data analysis for X-ray absorption spectroscopy using IFEFFIT. Journal of synchrotron radiation 12, 537-541 (2005).

58. Harrison, W. \& Trotter, J. Crystal and molecular structure of cadmium diacetate dihydrate. Journal of the Chemical Society, Dalton Transactions 956-960 (1972).

59. Kinniburgh, D. G. et al. Ion binding to natural organic matter: competition, heterogeneity, stoichiometry and thermodynamic consistency. Colloids and Surfaces A: Physicochemical and Engineering Aspects 151, 147-166 (1999).

60. Kinniburgh, D. G. et al. Metal ion binding by humic acid: application of the NICA-Donnan model. Environmental Science \& Technology 30, 1687-1698 (1996).

61. Meng, F., Yuan, G., Wei, J., Bi, D. \& Wang, H. Leonardite-derived humic substances are great adsorbents for cadmium. Environmental Science and Pollution Research 24, 23006-23014 (2017).

62. Liu, C., Frenkel, A. I., Vairavamurthy, A. \& Huang, P. M. Sorption of cadmium on humic acid: Mechanistic and kinetic studies with atomic force microscopy and X-ray absorption fine structure spectroscopy. Canadian Journal of Soil Science 81, 337-348 (2001).

63. de Melo, B. A. G., Motta, F. L. \& Santana, M. H. A. Humic acids: Structural properties and multiple functionalities for novel technological developments. Materials Science and Engineering: C 62, 967-974 (2016).

64. Von Wandruszka, R., Ragle, C. \& Engebretson, R. The role of selected cations in the formation of pseudomicelles in aqueous humic acid. Talanta 44, 805-809 (1997).

65. Avena, M. J., Vermeer, A. W. P. \& Koopal, L. K. Volume and structure of humic acids studied by viscometry: $\mathrm{pH}$ and electrolyte concentration effects. Colloids and Surfaces A: Physicochemical and Engineering Aspects 151, 213-224 (1999).

66. Tombácz, E. Colloidal properties of humic acids and spontaneous changes of their colloidal state under variable solution conditions. Soil Science 164, 814-824 (1999). 
667

668

669

670

671

672

673

674

675

676

677

678

679

680

681

682

683

684

685

686

687

688

689

690

67. Dideriksen, K., Baker, J. A. \& Stipp, S. L. S. Equilibrium Fe isotope fractionation between inorganic aqueous Fe (III) and the siderophore complex, Fe (III)-desferrioxamine B. Earth and Planetary Science Letters 269, 280-290 (2008).

68. Jouvin, D., Louvat, P., Juillot, F., Maréchal, C. N. \& Benedetti, M. F. Zinc isotopic fractionation: why organic matters. Environmental science \& technology 43, 5747-5754 (2009).

69. Bigalke, M., Weyer, S. \& Wilcke, W. Copper isotope fractionation during complexation with insolubilized humic acid. Environmental science \& technology 44, 5496-5502 (2010).

70. Ryan, B. M., Kirby, J. K., Degryse, F., Scheiderich, K. \& McLaughlin, M. J. Copper isotope fractionation during equilibration with natural and synthetic ligands. Environmental science \& technology 48, 8620-8626 (2014).

71. Juillot, F. et al. Zn isotopic fractionation caused by sorption on goethite and 2-Lines ferrihydrite. Geochimica et Cosmochimica Acta 72, 4886-4900 (2008).

72. Guinoiseau, D., Gélabert, A., Moureau, J., Louvat, P. \& Benedetti, M. F. Zn isotope fractionation during sorption onto kaolinite. Environmental science \& technology 50, 1844-1852 (2016).

73. Bigeleisen, J. \& Mayer, M. G. Calculation of equilibrium constants for isotopic exchange reactions. The Journal of Chemical Physics 15, 261-267 (1947).

74. Schauble, E. A. Applying stable isotope fractionation theory to new systems. Reviews in Mineralogy and Geochemistry 55, 65-111 (2004).

75. Yang, J. et al. Theoretical calculations of Cd isotope fractionation in hydrothermal fluids. Chemical Geology 391, 74-82 (2015).

76. Ohtaki, H. \& Johansson, G. X-ray diffraction studies on the structures of cadmium iodide complexes in water and in DMSO solutions. Pure and Applied Chemistry 53, 1357-1364 (1981).

77. Mohammed, A. M. Hydration of Cd (II): molecular dynamics study. Bulletin of the Chemical Society of Ethiopia 22, (2008). 
78. Boyanov, M. I. et al. Adsorption of cadmium to Bacillus subtilis bacterial cell walls: a pHdependent X-ray absorption fine structure spectroscopy study. Geochimica et Cosmochimica Acta 67, 3299-3311 (2003).

79. Vasconcelos, I. F., Haack, E. A., Maurice, P. A. \& Bunker, B. A. EXAFS analysis of cadmium (II) adsorption to kaolinite. Chemical Geology 249, 237-249 (2008).

80. Bazarkina, E. F., Pokrovski, G. S., Zotov, A. V. \& Hazemann, J.-L. Structure and stability of cadmium chloride complexes in hydrothermal fluids. Chemical Geology 276, 1-17 (2010).

81. Wiggenhauser, M. et al. Cadmium transfer in contaminated soil-rice systems: Insights from solidstate speciation analysis and stable isotope fractionation. Environmental Pollution 269, 115934 (2021).

82. Gondar, D., López, R., Fiol, S., Antelo, J. M. \& Arce, F. Cadmium, lead, and copper binding to humic acid and fulvic acid extracted from an ombrotrophic peat bog. Geoderma 135, 196-203 (2006).

83. Carrasquero-Durán, A. \& Flores, I. Cadmium Binding by Humic Acids: An Experiment in FTIR Spectroscopy and Soil Chemistry. Chem. Educ. 9, 1-4 (2004).

84. Karlsson, T., Persson, P. \& Skyllberg, U. Extended X-ray absorption fine structure spectroscopy evidence for the complexation of cadmium by reduced sulfur groups in natural organic matter. Environmental science \& technology 39, 3048-3055 (2005).

85. Isaure, M.-P. et al. Evidence of various mechanisms of $\mathrm{Cd}$ sequestration in the hyperaccumulator Arabidopsis halleri, the non-accumulator Arabidopsis lyrata, and their progenies by combined synchrotron-based techniques. Journal of experimental botany 66, 3201-3214 (2015).

86. Imseng, M. et al. Towards an understanding of the $\mathrm{Cd}$ isotope fractionation during transfer from the soil to the cereal grain. Environmental pollution 244, 834-844 (2019).

87. Huggins, M. L. Bond energies and polarities1. Journal of the American Chemical Society 75, 41234126 (1953). 
88. Hiemstra, T. \& Van Riemsdijk, W. H. On the relationship between charge distribution, surface hydration, and the structure of the interface of metal hydroxides. Journal of colloid and interface science 301, 1-18 (2006).

89. Carbonaro, R. F. \& Di Toro, D. M. Linear free energy relationships for metal-ligand complexation: monodentate binding to negatively-charged oxygen donor atoms. Geochimica et cosmochimica acta 71, 3958-3968 (2007).

90. Wilkins, R. G. Mechanisms of ligand replacement in octahedral nickel (II) complexes. Accounts of Chemical Research 3, 408-416 (1970).

91. Elias, H. R. G. Wilkins: Kinetics and Mechanism of Reactions of Transition Metal Complexes, 2nd Thoroughly Revised Edition. VCH, Weinheim 1991. ISBN 3-527-28389-7. 482 Seiten. Preis (Softcover): DM 68.00. Berichte der Bunsengesellschaft für physikalische Chemie 96, 638-639 (1992).

92. Chillemi, G. et al. Computational evidence for a variable first shell coordination of the cadmium (II) ion in aqueous solution. The Journal of Physical Chemistry B 109, 9186-9193 (2005).

93. Pye, C. C., Tomney, M. R. \& Rudolph, W. W. Cadmium hydration: hexacoordinate or heptacoordinate? Canadian Journal of Analytical Sciences and Spectroscopy 51, 140-146 (2006).

94. D’Angelo, P., Migliorati, V., Mancini, G. \& Chillemi, G. A coupled molecular dynamics and XANES data analysis investigation of aqueous cadmium (II). The Journal of Physical Chemistry A 112, 11833-11841 (2008).

95. Saito, T., Nagasaki, S., Tanaka, S. \& Koopal, L. K. Electrostatic interaction models for ion binding to humic substances. Colloids and Surfaces A: Physicochemical and Engineering Aspects 265, 104113 (2005).

96. Mendoza-Cózatl, D. G., Jobe, T. O., Hauser, F. \& Schroeder, J. I. Long-distance transport, vacuolar sequestration, tolerance, and transcriptional responses induced by cadmium and arsenic. Current opinion in plant biology 14, 554-562 (2011). 
97. Vogel-Mikuš, K., Arčon, I. \& Kodre, A. Complexation of cadmium in seeds and vegetative tissues of the cadmium hyperaccumulator Thlaspi praecox as studied by X-ray absorption spectroscopy. Plant and Soil 331, 439-451 (2010).

98. Huguet, S. et al. Cd speciation and localization in the hyperaccumulator Arabidopsis halleri. Environmental and Experimental Botany 82, 54-65 (2012).

99. Ueno, D., Ma, J. F., Iwashita, T., Zhao, F.-J. \& McGrath, S. P. Identification of the form of Cd in the leaves of a superior Cd-accumulating ecotype of Thlaspi caerulescens using 113 Cd-NMR. Planta 221, 928-936 (2005).

100. Tian, S. et al. Cellular sequestration of cadmium in the hyperaccumulator plant species Sedum alfredii. Plant Physiology 157, 1914-1925 (2011).

101. Xue, Z. et al. Cadmium isotope variations in the Southern Ocean. Earth and Planetary Science Letters 382, 161-172 (2013).

102. Xie, R. C. et al. Non-Rayleigh control of upper-ocean Cd isotope fractionation in the western South Atlantic. Earth and planetary science letters 471, 94-103 (2017).

103. Bruland, K. W. Complexation of cadmium by natural organic ligands in the central North Pacific. Limnology and Oceanography 37, 1008-1017 (1992).

104. Ellwood, M. J. Zinc and cadmium speciation in subantarctic waters east of New Zealand. Marine Chemistry 87, 37-58 (2004).

105. Baars, O., Abouchami, W., Galer, S. J., Boye, M. \& Croot, P. L. Dissolved cadmium in the Southern Ocean: Distribution, speciation, and relation to phosphate. Limnology and Oceanography 59, 385399 (2014).

106. Louis, Y. et al. Characterisation and modelling of marine dissolved organic matter interactions with major and trace cations. Marine Environmental Research 67, 100-107 (2009).

107. Pokrovsky, O. S., Pokrovski, G. S., Gélabert, A., Schott, J. \& Boudou, A. Speciation of Zn associated with diatoms using X-ray absorption spectroscopy. Environmental science \& technology 39, 4490-4498 (2005). 
767 108. Gélabert, A. et al. Interaction between zinc and freshwater and marine diatom species: surface 768 complexation and $\mathrm{Zn}$ isotope fractionation. Geochimica et Cosmochimica Acta 70, 839-857 (2006).

769 109. Sieber, M. et al. Physical and biogeochemical controls on the distribution of dissolved cadmium and 770 its isotopes in the Southwest Pacific Ocean. Chemical Geology 511, 494-509 (2019). 